\title{
Antarctic ice shelf potentially stabilized by export of meltwater in surface river
}

Robin E. Bell ${ }^{1}$, Winnie Chu ${ }^{1,2}$, Jonathan Kingslake ${ }^{1,2}$, Indrani Das ${ }^{1}$, Marco Tedesco ${ }^{1,3}$, Kirsty J. Tinto ${ }^{1}$, Christopher J. Zappa ${ }^{1}$, Massimo Frezzotti ${ }^{4}$, Alexandra Boghosian ${ }^{1,2} \&$ Won Sang Lee Le, $^{5,}$

\begin{abstract}
Meltwater stored in ponds ${ }^{1}$ and crevasses can weaken and fracture ice shelves, triggering their rapid disintegration ${ }^{2}$. This ice-shelf collapse results in an increased flux of ice from adjacent glaciers ${ }^{3}$ and ice streams, thereby raising sea level globally ${ }^{4}$. However, surface rivers forming on ice shelves could potentially export stored meltwater and prevent its destructive effects. Here we present evidence for persistent active drainage networks-interconnected streams, ponds and rivers-on the Nansen Ice Shelf in Antarctica that export a large fraction of the ice shelf's meltwater into the ocean. We find that active drainage has exported water off the ice surface through waterfalls and dolines for more than a century. The surface river terminates in a 130-metre-wide waterfall that can export the entire annual surface melt over the course of seven days. During warmer melt seasons, these drainage networks adapt to changing environmental conditions by remaining active for longer and exporting more water. Similar networks are present on the ice shelf in front of Petermann Glacier, Greenland, but other systems, such as on the Larsen C and Amery Ice Shelves, retain surface water at present. The underlying reasons for export versus retention remain unclear. Nonetheless our results suggest that, in a future warming climate, surface rivers could export melt off the large ice shelves surrounding Antarctica-contrary to present Antarctic ice-sheet models ${ }^{1}$, which assume that meltwater is stored on the ice surface where it triggers ice-shelf disintegration.
\end{abstract}

Ponded meltwater on the Larsen B Ice Shelf before its collapse has become emblematic of the destructive role of stored meltwater. The glaciers feeding Larsen B experienced a notable speed-up after the ice shelf's 2002 collapse ${ }^{2}$. Meltwater stored in ponds loads, flexes and weakens an ice shelf ${ }^{3}$. Meltwater also deepens crevasses ${ }^{3}$. As global temperatures rise, more meltwater will form atop the ice shelves that ring Antarctica ${ }^{5}$. Ice-sheet models that project future sea-level rise include an ice-shelf hydro-fracturing mechanism that is linked to surface melting ${ }^{4}$. These models funnel the surface melt into crevasses at the grounding line (the point at which a forward-moving glacier loses contact with the ground, becoming a floating ice shelf) and calving front, where this stored water deepens the crevasses through hydro-fracturing ${ }^{6}$, eventually triggering the collapse of the ice shelves and the rapid retreat of the Antarctic ice sheets.

To understand the role of increased surface melt, we examine the Nansen Ice Shelf, where surface melt is already widespread and surface ablation is around $0.5 \mathrm{~m} \mathrm{yr}^{-1}$. Located along the edge of the Ross Sea, the $\left(1,800 \mathrm{~km}^{2}\right)$ Nansen forms where the Priestley and Reeves Glaciers go afloat and merge ${ }^{7}$ (Fig. 1). There is no evidence for recent collapse of the Nansen, or of the adjacent Hells Gate Ice Shelf. Both have persisted throughout the warming period of the late Holocene era, advancing after around 5,800 years BP to their present extent ${ }^{8}$. Strong katabatic winds scour much of the ice surface of the Nansen blue ice. An elongate, low-lying shear margin separates ice from the Reeves and Priestley
Glaciers (at $20 \mathrm{~km}$; Fig. 1b; ref. 9). South of the shear margin, the Reeves Glacier ice contains oblique 1.5-4.5 $\mathrm{m}$ deep, 7-10 km long depressions that are similar to the surface expression of basal melting in Pine Island Glacier $^{10}$ (Fig. 1b, R1 and R2). North of the shear margin, the Priestley Glacier ice contains 1-4 $\mathrm{m}$ deep linear troughs. The deepest of these troughs (P2, P3 and P4 in Fig. 1b) are associated with thinner ice ${ }^{11}$ and overlie basal crevasses ${ }^{12}$ (Fig. 1c).

Water was first observed on the Nansen Ice Shelf in 1909, by Ernest Shackleton's Nimrod team traversing towards the magnetic South Pole. T. W. E. David noted that a "thaw-water stream could be heard roaring"13 along the southern edge of the ice shelf. Three years later, the Northern Party team of Scott's British Antarctic Expedition spent January 1912 mapping the Nansen Ice Shelf. Approaching the Priestley Glacier grounding line, the team reported that the "noise of running water from a lot of streams sounded odd after the usual Antarctic silence" 14 . The Northern Party described surface melt forming adjacent to outcropping rocks and lateral moraines. They crossed thaw channels, streams, marginal ponds and a $15 \mathrm{~m}$ deep, $50 \mathrm{~m}$ wide ravine (Fig. 2, Extended Data Fig. 1 and Extended Data Table 1) containing flowing water ${ }^{15}$. The Northern Party repeatedly fell into thaw ponds and ice-covered streams ${ }^{14,15}$ and water filled the base of their tents ${ }^{16}$.

Here, we used airborne imagery (from 1956 to 1975) and satellite remote sensing (from 1974 to 2014) to document the persistence and extent of surface melt. We also estimated the volume of water exported off the ice shelf into the ocean. Using catchment analysis and satellite imagery, we identified three types of ice-shelf drainage. Close to the Priestley Glacier grounding line, a catchment basin terminates in firn (recrystallized compacted snow from previous seasons), while a catchment close to the Reeves Glacier grounding line drains onto ice mélange that fills rifts in the ice shelf. On the outer shelf, a shear-margin catchment feeds a river that develops along the low-lying shear margin (Fig. 1a). All of these systems are active during the melt season.

The Priestley Glacier firn-terminating catchment begins at the grounding line, where meltwater forms in December along moraines and exposed bedrock (Fig. 2 and Extended Data Fig. 2). These ponds drain into the $15 \mathrm{~m}$ deep, water-filled ravine that was mapped in 1912 by the Northern Party (Fig. 2b). During the melt season, water fills marginal crevasses and flows around $20 \mathrm{~km}$ down the ice shelf across blue ice into the section of the ice shelf with thicker surface snow, where it probably saturates the firn and feeds firn aquifers. Similar firn-terminating streams have been observed on the Amery ${ }^{17}$ and Nivilsen ${ }^{18}$ ice shelves, as well as in Dronning Maud Land ${ }^{19,20}$ in East Antarctica.

The mélange-terminating Reeve Glacier grounding-line catchment, first observed in 1909, was resolved by airborne imagery in 1961 and 1975 and by commercial high-resolution satellite images from 2014 (Extended Data Fig. 2). The surface meltwater entering these rifts drains into the sub-ice cavity and may explain the relative freshness of 
a

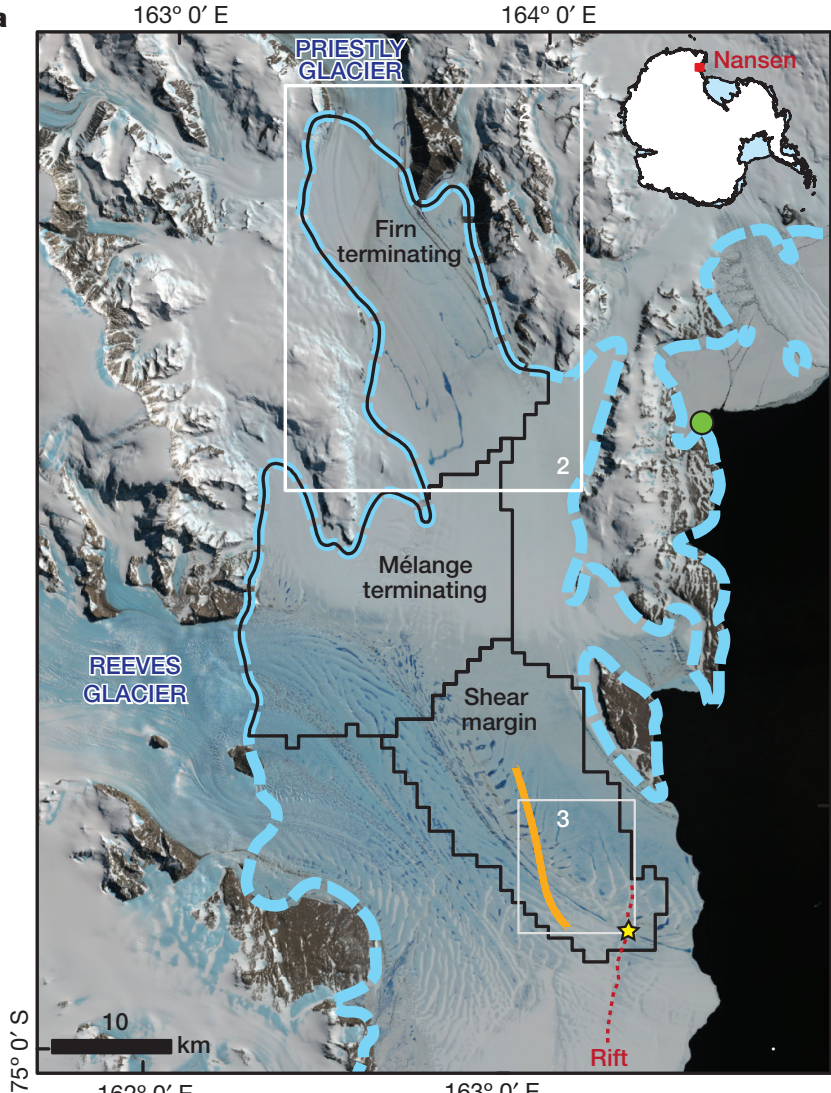

Figure 1 | Surface hydrology and topography of Nansen Ice Shelf. a, Landsat image of the Nansen Ice Shelf, showing three drainage catchments (outlined in black); the line of flight of the NASA IceBridge mission (mango); the waterfall location (star); the grounding line (blue solid and dashed lines); and the ice-shelf rift (red dotted line). White boxes indicate the locations studied for Figs 2, 3. The green dot indicates b
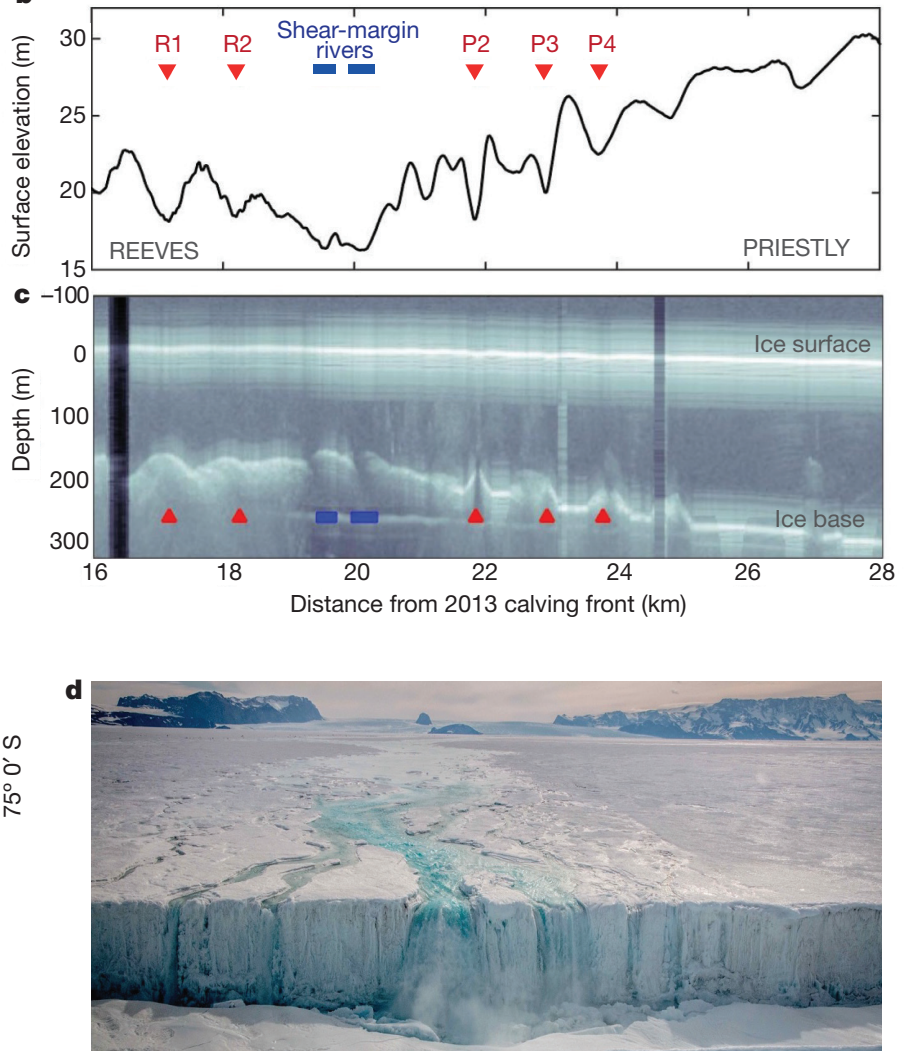

the location of the Mario Zucchelli Station weather observatory on Hells Gate Ice Shelf. b, IceBridge ice surface elevation profile across the shearmargin river and adjacent basins ${ }^{9}$. R1 and R2 are 1.5-4.5 m deep, $7-10 \mathrm{~km}$ long depressions; P2, P3 and P4 are 1-4 m deep troughs. c, IceBridge radar profile $^{11}$. d, Water export off the shelf at a $130 \mathrm{~m}$ wide shear-margin river waterfall on 12 January 2014; photo credit: Robert Fletcher.

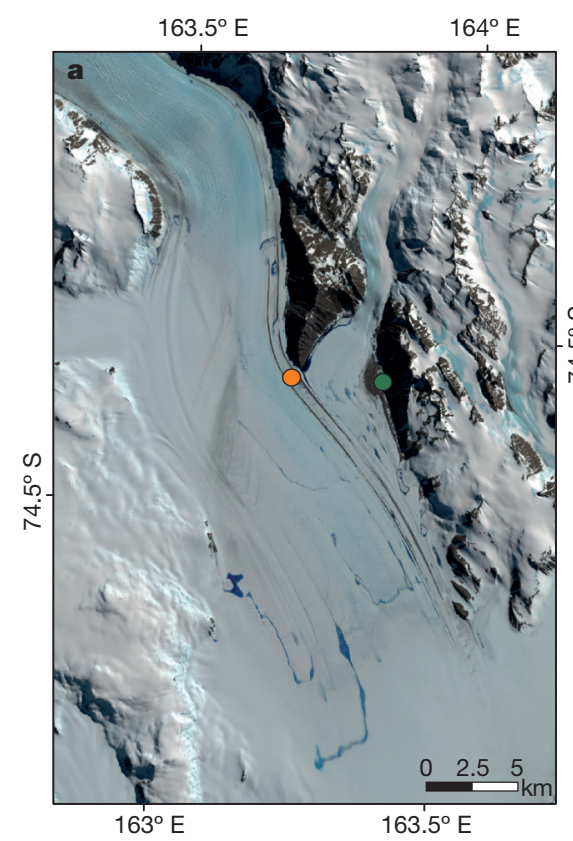

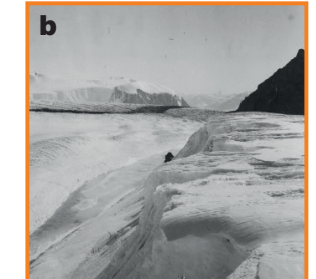
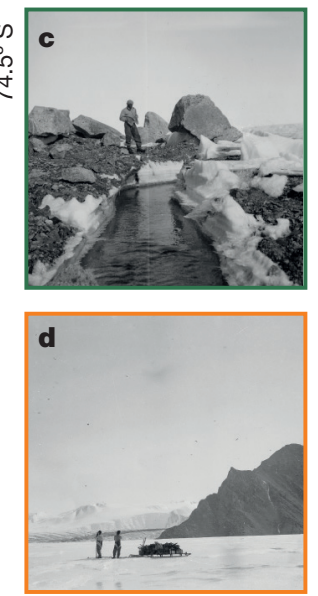
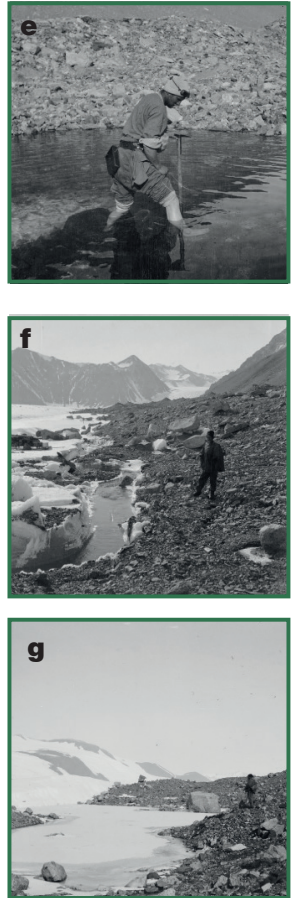

Figure $2 \mid$ Photographs of the Nansen Ice Shelf taken by the 1912 Northern Party. a, This Landsat image, taken on 26 December 2013, shows the locations depicted in the photographs at the right. b, Deep, water-filled ravine. c, Surface stream on ice-shelf margin. d, Two men with a sledge on the ice shelf, showing ponded water. e, Raymond Priestley wading barefoot in water on the ice-shelf margin. f, Surface stream. g, Frozen pond. Greenbordered photos are from Corner Glacier (green dot) on the eastern side of the ice shelf. Yellow-bordered photos were taken close to the moraine camp (yellow dot). Photo credits: Frank Debenham. Locations of Northern Party camps are presented in Extended Data Table 1. 

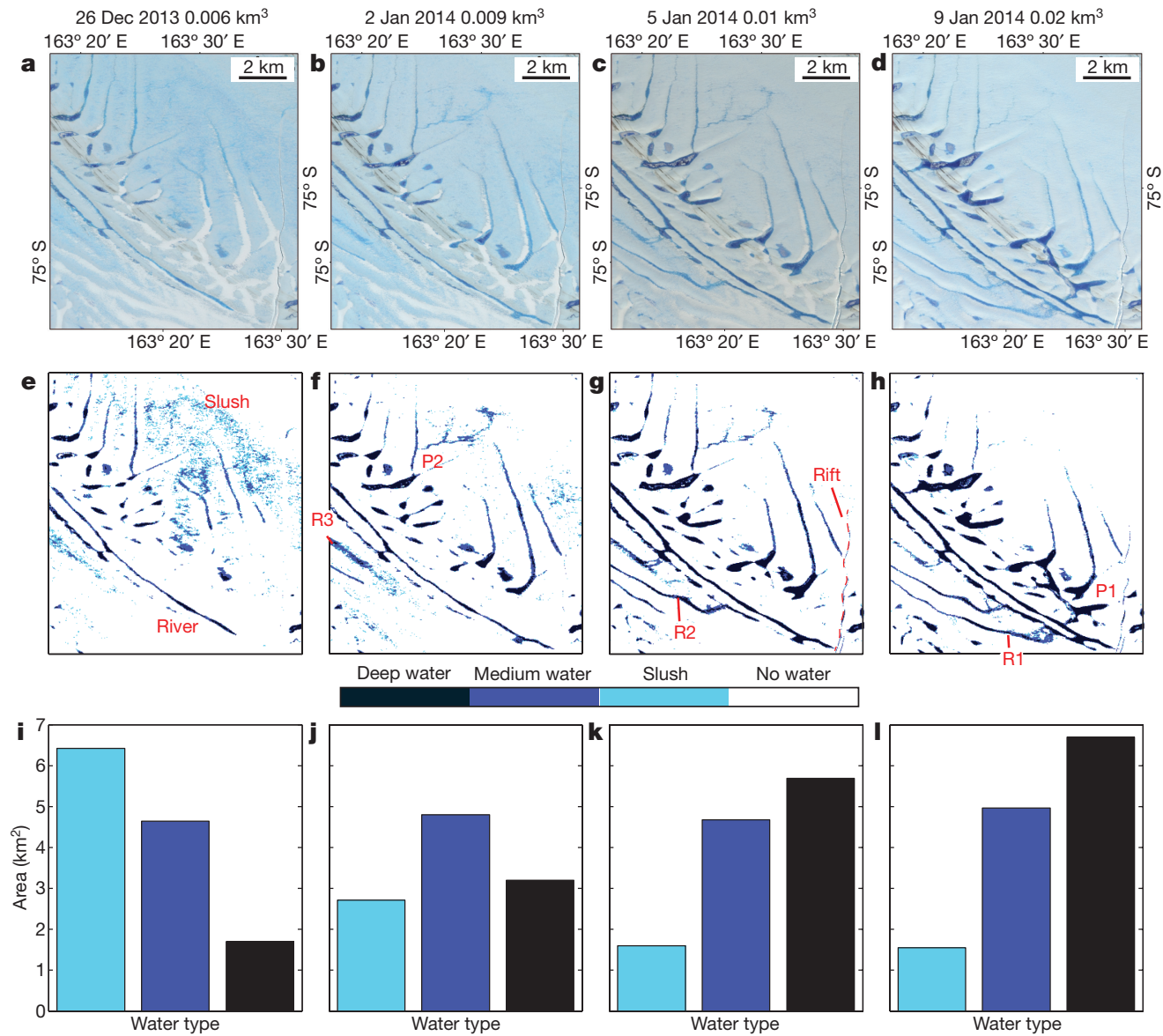

Figure 3 | Evolution of the extent and depth of meltwater during the melt season. a-d, Landsat imagery of the shear-margin river from 26 December 2013 to 9 January 2014. The river's location is shown in Fig. 1. e-h, Distribution of shallow/slushy water (less than $0.2 \mathrm{~m}$ deep), medium-deep water (0.2-1 $\mathrm{m}$ deep) and deep water (more than $1 \mathrm{~m}$ deep). The extent of shallow/slush water is $0.12<\mathrm{NDWI}_{\text {ice }}<0.14$, of

medium-deep water is $0.14<\mathrm{NDWI}_{\text {ice }}<0.25$, and of deep water or ponds is $\mathrm{NDWI}_{\text {ice }}>0.25$. $\mathbf{i}-\mathbf{l}$, The fraction of surface area that is characterized by slush, medium and deep water. Ice-shelf water evolves from being predominantly shallow in December to predominantly deep in January. Sensitivity analysis and location are shown in Extended Data Fig. 4. Water extent and depths shown in Extended Data Fig. 5.

the ice recovered from drilling into these rifts ${ }^{21}$. This connectivity of surface melt drainage to the underlying ocean is similar to the dolines (sinkholes) observed on the Larsen $\mathrm{C}^{22}$ and Amery ${ }^{23}$ ice shelves.

The majority of water exported from the ice shelf drains along the shear-margin depression, across the shear-margin catchment. Little surface debris remains on the ice shelf within this catchment. The widespread meltwater within this catchment was first resolved by a 1974 Landsat image and by airborne imagery in 1975 (Extended Data Fig. 3). In years during which the temperature is high and large volumes of melt are produced, a river forms along the low-lying shear margin and terminates at an ice-edge waterfall. Between December 1989 and January 2016, the waterfall was recorded in Landsat imagery tumbling into a developing rift in the ice shelf. The rift gradually widened until a calving event occurred in early April 2016. Similar-sized calving events have occurred twice in the twentieth century ${ }^{24}$ (Methods). However, the presence of persistent surface water on the Nansen Ice Shelf has not triggered catastrophic ice-shelf collapse. Before the 2006-2007 melt season, the satellite record is too sporadic to determine how and when the waterfall forms. The Nansen shear-margin river exported water off the ice shelf in six of the eight melt seasons between 2006 and 2015, for which satellite coverage is sufficient to determine the extent of the drainage system (Extended Data Table 2).

The development of a drainage system that exported water was well documented during the 2013-2014 and 2008-2009 (see Supplementary Videos) melt seasons. For 2013-2014, we used Landsat-8 multispectral data to map water extent $t^{25}$ and depth across the shear-margin catchment ${ }^{25}$ (see Methods). We determined water extent by using the

normalized difference water index adapted for ice $\left(\mathrm{NDWI}_{\mathrm{ice}}\right)^{25}$ and water depth by using the attenuation of the water-leaving reflectance in the Landsat- 8 blue channel (Fig. 3 and Extended Data Figs 4, 5). On 26 December 2013, shallow surface melt (slush) was widespread on the ice shelf and water was beginning to concentrate in the shear margin river, drawing from two inland ponds. One week later (2 January 2014), the widespread shallow water had coalesced into the surface ponds; two additional ponds on the Priestly Glacier side (P2 and P3 in Fig. 1b) had drained into the river; and the waterfall was exporting water. By 5 January, two additional ponds (R2 and R3) on the Reeves Glacier side were draining into the river. By 9 January, the furthest downstream ponds on both sides of the shear margin (R1 and P1) had connected with the river. The connectivity between the ponds and the river propagated downstream towards the calving front. Thus, over the course of two weeks, an interconnected system of streams and ponds evolved to export water at the waterfall.

For eight melt seasons, sufficient satellite coverage is available to track the development of ice-shelf hydrology, quantify the duration of meltwater export and estimate the volume of meltwater exported. When the waterfall forms, it exports water for 5-25 days, persisting for longer when the temperatures are higher. The temperature record from Mario Zucchelli Station (Fig. 1) shows that the two years during which no waterfall was observed (2006-2007 and 2009-2010) were the coolest. The waterfall's duration increases as the number of days during which the minimum temperature is above the melting point $\left(0^{\circ} \mathrm{C}\right)$ at Mario Zucchelli Station increases (Extended Data Figs 6, 7). More water is exported during warmer years. As environmental forcing changes 

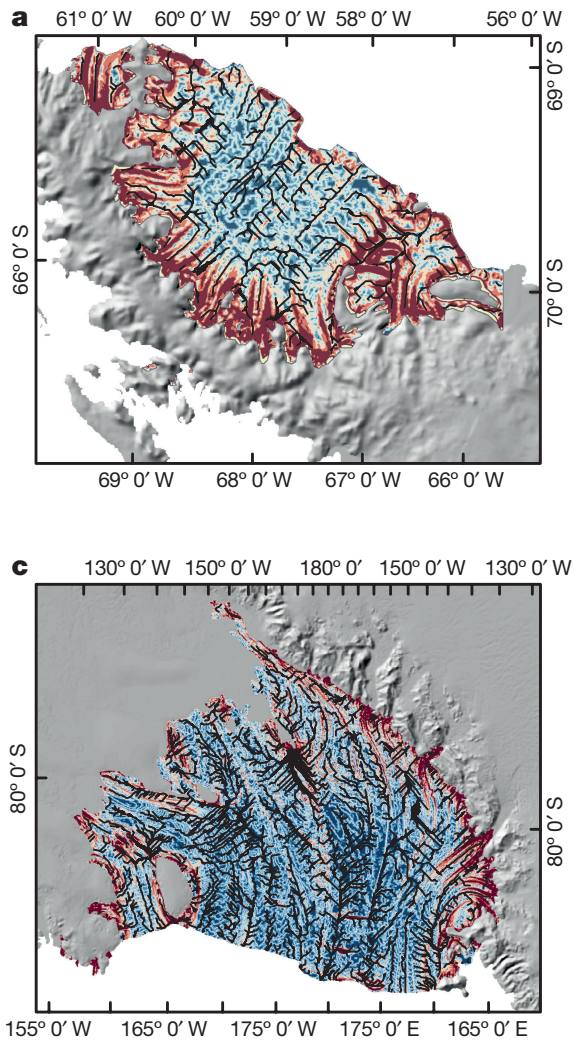

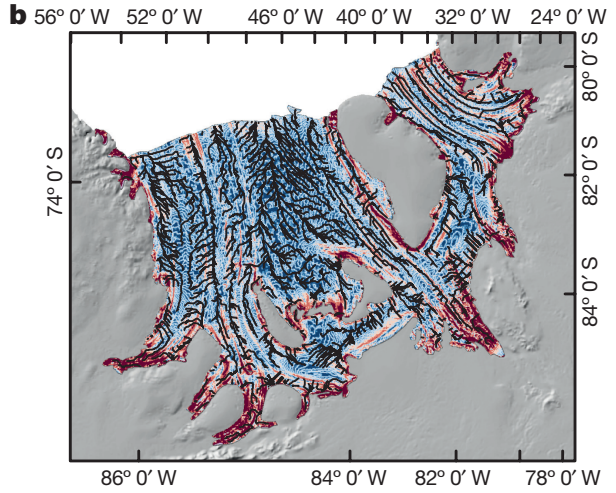

d

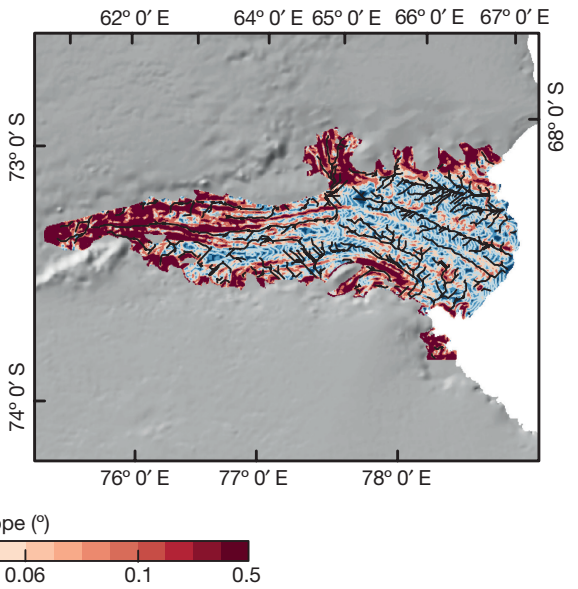

Figure 4 | Surface meltwater routing on Antarctic ice shelves. a, Larsen C (average slope $0.14^{\circ}$ ). b, Filchner-Ronne (average slope $0.03^{\circ}$ ). c, Ross (average slope: $0.04^{\circ}$ ). $\mathbf{d}$, Amery (average slope $0.07^{\circ}$ ). The routing, in black, is overlain on surface slopes. The convergence of flow from different

and meltwater production increases, the ice-shelf drainage system adapts, exporting more surface meltwater.

We estimated the volume of surface melt exported off the ice shelf by using Manning's equation, which is based on airborne laser topographic measurements ${ }^{9}$ and on Landsat satellite imagery (Methods). The river drained towards the waterfall with flow speeds of $1.39-2.17 \mathrm{~m} \mathrm{~s}^{-1}$ and fluxes of around $259-806 \mathrm{~m}^{3}$. Velocities determined through feature tracking from a helicopter-based video provided slightly lower estimates (see Methods). We quantified the volume of water exported each melt season by using the waterfall export duration and the minimum flux from the Manning approach $\left(260 \mathrm{~m}^{3} \mathrm{~s}^{-1}\right)$. The calculated water export ranges from $0.04 \mathrm{~km}^{3}$ to $0.56 \mathrm{~km}^{3}$ in each season. In just seven days, the waterfall can export the entire annual surface melt volume produced by a melt rate of $0.5 \mathrm{~m} \mathrm{yr}^{-1}$ over the shear-margin catchment. Present ice-sheet models produce rapid disintegration when surface melt rates reach $1.5 \mathrm{~m} \mathrm{yr}^{-1}$. However, our results show that this amount of surface melt could be removed by the waterfall in 21 days (Extended Data Fig. 6). This efficient export of surface meltwater highlights the capacity of rivers to efficiently buffer ice shelves against the damaging storage of melt.

The surface melt rate of $0.5 \mathrm{~m} \mathrm{yr}^{-1}$ on the Nansen Ice Shelf may be representative of ice-shelf hydrology in the future. With the exception of the ice shelves on the Antarctic Peninsula, the surface melt rates on Antarctic ice shelves are presently relatively low. With surface melt rates projected to increase, a key question is whether Nansen-style drainage systems will develop elsewhere and export water off the ice shelves. Using surface digital elevation models (DEMs) ${ }^{26}$, we analysed possible surface drainage networks of four large ice shelves-Amery, FilchnerRonne, Larsen C and Ross-using a simple routing algorithm (Fig. 4; Methods). Some ice-sheet models project that these ice shelves will glaciers forms topographic troughs and steeper surface slopes on ice shelves. Water will coalesce and be preferentially exported off the ice shelves along linear troughs. The mean slope of the Nansen Ice Shelf shearmargin catchment is $0.11^{\circ}$.

disintegrate quickly after the surface melt exceeds $1.5 \mathrm{~m} \mathrm{yr}^{-1}$ within the next century ${ }^{4}$. Our analysis, however, suggests that drainage networks aligned along troughs could form where ice-flow units of variable thickness and velocity meet at shear margins, similar to the shear-margin river on Nansen Ice Shelf. As surface melt increases, shear-margin rivers may develop on these other ice shelves, extending up to hundreds of kilometres inland (for example, $80 \mathrm{~km}$ inland on Amery, $65 \mathrm{~km}$ on Larsen B, $350 \mathrm{~km}$ on Ross and $440 \mathrm{~km}$ on Filchner).

The large-scale morphology of future drainage networks will depend on surface and basal mass balance as well as ice-shelf strain rates. Our results show (for the first time, to our knowledge) that surface meltwater on an ice shelf can be exported off the ice shelf through a hydrologic system that evolves as melt increases. We suggest that river networks that facilitate meltwater export will develop on other ice shelves as melt rates increase. Ice-shelf rivers are presently active in northern Greenland (on Petermann Glacier; Extended Data Fig. 8). These rivers, which reduce the stored surface water, will form when the ice-surface slope is sufficiently steep and the storage capacity in firn aquifers, ponds and crevasses is limited. The slope of an ice shelf's surface is strongly controlled by the thickness of incoming ice and by the basal melt rate, which is driven by ocean temperatures. The ice-surface mass balance is controlled by surface accumulation, the persistence of katabatic winds and run-off. Comparing the atmosphere and oceanographic conditions for ice shelves with surface rivers (Nansen, Petermann, and possibly $79 \mathrm{~N}$ in Greenland) with ice shelves on which water is retained at present (Larsen C and Amery) will advance our understanding of the role of surface river export in a warming world.

At present, surface meltwater is being produced and transported onto ice shelves around Antarctica ${ }^{27}$ and is expected to increase in the future. The dynamic nature of the Nansen surface hydrology 
highlights the need to accurately model surface water extent and flow across ice shelves. Export of meltwater by surface rivers may buffer the impact of warming temperatures. Thus a realistic representation of ice-shelf plumbing and surface hydrology will be essential in accurately projecting the future of Antarctica's marine ice sheets and their potential contribution to sea levels.

Online Content Methods, along with any additional Extended Data display items and Source Data, are available in the online version of the paper; references unique to these sections appear only in the online paper.

\section{Received 6 July 2016; accepted 2 March 2017.}

1. Vieli, A., Payne, A. J., Shepherd, A. \& Du, Z. Causes of pre-collapse changes of the Larsen B ice shelf: numerical modelling and assimilation of satellite observations. Earth Planet. Sci. Lett. 259, 297-306 (2007).

2. Scambos, T. A., Bohlander, J. A., Shuman, C. U. \& Skvarca, P. Glacier acceleration and thinning after ice shelf collapse in the Larsen B embayment, Antarctica. Geophys. Res. Lett. 31, L18402 (2004).

3. Scambos, T. et al. Ice shelf disintegration by plate bending and hydro-fracture: satellite observations and model results of the 2008 Wilkins ice shelf break-ups. Earth Planet. Sci. Lett. 280, 51-60 (2009).

4. DeConto, R. M. \& Pollard, D. Contribution of Antarctica to past and future sea-level rise. Nature 531, 591-597 (2016).

5. Trusel, L. D. et al. Divergent trajectories of Antarctic surface melt under two twenty-first-century climate scenarios. Nat. Geosci. 8, 927-932 (2015).

6. Pollard, D., DeConto, R. M. \& Alley, R. B. Potential Antarctic Ice Sheet retreat driven by hydrofracturing and ice cliff failure. Earth Planet. Sci. Lett. 412, 112-121 (2015)

7. Frezzotti, M. Glaciological study in Terra Nova Bay, Antarctica, inferred from remote sensing analysis. Ann. Glaciol. 17, 63-71 (1993).

8. Hall, B. L. Holocene glacial history of Antarctica and the sub-Antarctic islands. Quat. Sci. Rev. 28.21, 2213-2230 (2009).

9. Studinger, M. S. IceBridge ATM L1B elevation and return strength, version 2. NASA National Snow and Ice Data Center Distributed Active Archive Center. Boulder, Colorado, USA. http://dx.doi.org/10.5067/19SIM5TXKPGT (2013, updated 2017)

10. Dutrieux, P. et al. Basal terraces on melting ice shelves. Geophys. Res. Lett. 41, 5506-5513 (2014)

11. Leuschen, C. et al. IceBridge MCoRDS L1B geolocated radar echo strength profiles, version 2. NASA National Snow and Ice Data Centere Distributed Active Archive Center, Boulder, Colorado, USA. http://dx.doi. org/10.5067/90S1XZRBAX5N (2014, updated 2016).

12. Luckman, A. et al. Basal crevasses in Larsen $C$ Ice Shelf and implications for their global abundance. Cryosphere 6, 113-123 (2012).

13. David, T. W. E. \& Priestley, R. E. Geological Observations in Antarctica by the British Antarctic Expedition 1907-1909 (JP Lippincott, 1909).

14. Campbell, V. The Wicked Mate: The Antarctic Diary of Victor Campbell (Bluntisham Books, 1988).

15. Priestley, R. E. Antarctic Adventure: Scott's Northern Party (E.P. Dutton and Company, 1915)

16. Levick, G. M. British Antarctic Expedition Journal (Scott Polar Research Institute Archive Catalogue No. MS1423/1-4, 1912).

17. Fricker, H. A. et al. Redefinition of the Amery Ice Shelf, East Antarctica, grounding zone. J. Geophys. Res. 107, http://dx.doi.org/10.1029/ 2001JB000383 (2002)

18. Kingslake, J. \& Sole, A. Modelling channelized surface drainage of supraglacial lakes. J. Glaciol. 61, 185-199 (2015).
19. Winther, J.-G., Elvehøy, H., Bøggild, C. E., Sand, K. \& Liston, G. Melting, runoff and the formation of frozen lakes in a mixed snow and blue-ice field in Dronning Maud Land, Antarctica. J. Glaciol. 42, 271-278 (1996).

20. Leppäranta, M., Järvinen, O. \& Mattila, O.-P. Structure and life cycle of supraglacial lakes in Dronning Maud Land. Antarct. Sci. 25, 457-467 (2013).

21. Khazendar, A., Tison, J. L., Stenni, B., Dini, M. \& Bondesan, A. Significant marine-ice accumulation in the ablation zone beneath an Antarctic ice shelf. J. Glaciol. 47, 359-368 (2001).

22. Glasser, N. F. et al. Surface structure and stability of the Larsen C ice shelf, Antarctic Peninsula. J. Glaciol. 55, 400-410 (2009).

23. Mellor, M. \& McKinnon, G. The Amery Ice Shelf and its hinterland. Polar Rec. 10, 30-34 (1960).

24. Baroni, C., Frezzotti, M., Giraudi, C. \& Orombelli, G. Ice flow and surficial variation inferred from satellite image and aerial photograph analysis of Larsen ice tongue, Hells Gate and Nansen ice shelves (Victoria Land, Antarctica). Mem. Soc. Geol. Ital. 46, 69-80 (1991).

25. Yang, K. \& Smith, L. C. Supraglacial streams on the Greenland Ice Sheet delineated from combined spectral-shape information in high-resolution satellite imagery. IEEE Geosci. Remote Sens. Lett. 10, 801-805 (2013).

26. Fretwell, P. et al. Bedmap2: improved ice bed, surface and thickness datasets for Antarctica. Cryosphere 7, 375-393 (2013).

27. Kingslake, J. C. E., Ely, J. C., Das, I. \& Bell, R. E. Widespread movement of meltwater onto and across Antarctic ice shelves. Nature http://dx.doi.org/10.1038/nature22049 (this issue).

Supplementary Information is available in the online version of the paper.

Acknowledgements This work benefited from input on the Northern Party historical documents from M. Hopper and D. Webster, in addition to assistance from the staff of the Scott Polar Research Institute, University of Cambridge, UK. This work was supported by the National Science Foundation under Rosetta Project award 1443534; a National Science Foundation Graduate Research Fellowship award (DGE-16-44869); a National Science Foundation award (1341688); two NASA awards (IceBridge NNX16AJ65G and NNX14AH79G); a NASA Earth and Space Science fellowship (NNX15AN28H); a grant from the Old York Foundation; and a grant from the Korean Ministry of Oceans and Fisheries (PM16020)

Author Contributions R.E.B assembled the archival material and wrote the manuscript. All authors contributed to the manuscript and the overall interpretation. W.C. conducted the catchment analysis and the drainage, and assembled the laser and radar data. J.K. analysed the water area and depths. M.T. determined the water area and depth. I.D. conducted the sensitivity analysis of the water depths and distribution. K.J.T. developed the surface slope products required for the flux calculations. C.J.Z. determined the velocity and volume flow rate of the shear-margin river. M.F. collected the ablation and temperature data. A.B. mapped the water on the ice shelf in front of Petermann Glacier. W.S.L. collected the helicopter video of the river and waterfall that was used for the velocity analysis.

Author Information Reprints and permissions information is available at www.nature.com/reprints. The authors declare no competing financial interests. Readers are welcome to comment on the online version of the paper. Publisher's note: Springer Nature remains neutral with regard to jurisdictional claims in published maps and institutional affiliations. Correspondence and requests for materials should be addressed to R.E.B. (robinb@ldeo.columbia.edu).

Reviewer Information Nature thanks the anonymous reviewer(s) for their contribution to the peer review of this work. 


\section{METHODS}

Historical photographs and journals. We used original archival material from the Northern Party Expedition, part of the British Antarctic Expedition 1910-1913, together with published accounts and diaries to develop a full account of the historic observations of water on the Nansen Ice Shelf.

The Northern Party was the team from Scott's British Antarctic Expedition 1910-1913 who studied the Terra Nova Bay region. The Northern Party conducted six weeks of mapping from the Hells Gate Ice Shelf to the Priestley grounding line in early 1912. They documented the water systems and the fossil-rich moraines.

The Northern Party images used here (Fig. 2), taken by Frank Debenham, are archived at the Scott Polar Research Institute (SPRI) Library, University of Cambridge. Some of these images (Fig. 2b, c) were also published by C.S. Wright and Raymond Priestley in 1922 (ref. 28). The images are in the SPRI collection with the following identifiers: Fig. 2b, P54/16/311, Sandstone Glacier barranca or ravine with stream at base; Fig. 2c, P54/16/280, Corner Glacier stream; Fig. 2d, P54/16/307, Sandstone Glacier, two people with sledge and water; Fig. 2e, P54/16/372, Priestley wading for mirabilite; Fig. 2f, P54/16/279, Corner Glacier with sledge; Fig. $2 \mathrm{~g}$, Priestley Glacier with frozen pool. Locations of the major campsites were identified from the 1912 maps, and are presented in Extended Data Table 1 and shown in Extended Data Fig. 1.

The Nimrod Expedition was led by Ernest Shackleton in 1907-1909. In 1908, T.W. Edgeworth David, Douglas Mawson and Alistair Mackay crossed the Nansen Ice Shelf on their way to the East Antarctic Plateau in search of the magnetic South Pole. David was a keen observer of surface water throughout the expedition, mapping water on the Ferrar Glacier in addition to observing water on the Nansen Ice Shelf.

The original archival material reviewed for the Northern Party included the diaries of Victor Campbell, Priestley, Debenham and George Levick, which are preserved at the University of Cambridge Polar Research Institute in Cambridge, UK. Using the maps, journals and modern imagery, we located the photos of the surface water systems described by both the Northern Party and the Nimrod expedition.

Trimetrogon aerial photography. The US Navy collected trimetrogon aerial photography (TMA) over Antarctica beginning in 1946 with Operation Highjump. The TMA images were generally collected with three cameras, positioned to take simultaneous vertical, left oblique, and right oblique images. Along a single flight line, the oblique cameras were pointed $30^{\circ}$ off nadir. Each of the three cameras had an angular field of view of $60^{\circ}$, providing a $180^{\circ}$ horizon-to-horizon coverage when the images are placed side-by-side. The majority of images over the Nansen Ice Shelf are black-and-white photographs. Later flights include only single nadir colour images. The US Geological Survey (USGS) Earth Resources Observation and Science (EROS) Center scanned the US Antarctic film collection and worked with the Antarctic Geospatial Information Center (AGIC) to establish latitude and longitude coordinates for the single-frame records. The nominal resolution of the images varies with flight elevation. For the vertical images used over the Nansen, the high-resolution scans at 1,000 d.p.i. provide a resolution of $1-2 \mathrm{~m}$. We used the AGIC data browser to review the Nansen TMA imagery. The TMA mission number, roll number and frame number are essential, as some of the imagery required geolocation owing to positioning errors that became apparent upon image analysis. We reviewed the TMA imagery over the Nansen Ice Shelf from 2 December 1956, 8 and 9 January 1957, 14 January 1961, 8 January 1975, 11 November 1984, and 5 and 11 November 1985.

Extended Data Fig. 3 includes the TMA image of the 1975 waterfall that was taken on 8 January 1975 (TMA photograph identifier CA238432V0063, available from https://earthexplorer.usgs.gov). We have also included the Landsat image from 16 January 1974 (Landsat image scene identifier LM10641141974016AAA02, available from https://earthexplorer.usgs.gov), which also shows a well defined surface drainage network as well as a waterfall on the calving front.

IceBridge airborne data. We used NASA IceBridge data for the Nansen Ice Shelf to constrain the ice thickness and surface morphology of the shear-margin river and the surface ponds on the Reeves and Priestley Glacier sides. We used the airborne topographic mapper (ATM) laser altimetry ${ }^{9}$ and multichannel coherent radar depth sounder (MCoRDS) ice-penetrating radar data ${ }^{11}$ from the 19 November 2013 flight for this analysis (Fig. 1).

Landsat images. The Landsat images shown in the Supplementary Videos and in Figs 1 and 2 are pansharpened colour infrared composites obtained using Landsat- 8 channels 5 (near-infrared, $850-880 \mathrm{~nm}$ ), 4 (red, 640-670 nm) and 3 (green, $530-590 \mathrm{~nm}$ ).

Calculation of ice-shelf catchments and water routing. To determine the ice-shelf catchment area, we calculate water flow paths by applying a routing algorithm ${ }^{29}$ to the Bedmap2 surface elevation $\mathrm{DEM}^{26}$. No Worldview imagery over the ice shelf was available that could produce a high-resolution DEM. We evaluated other available DEMs and all produced similar catchments. The single IceBridge line was insufficient to produce a detailed DEM but closely matched the Bedmap2 surface.

We used a multiple-slope, D-infinity approach ${ }^{30}$ to calculate the flow direction after filling closed basins. These closed basins were interpreted as artefacts within the DEM, and were removed by raising their elevation iteratively to the point at which water overflows its confining pour point. We then summed the upstream contribution areas on the basis of the calculated flow directions, and delineated the surface water flow paths across the Nansen Ice Shelf. Next, we use these flow path to determine the ice-shelf catchment area. To delineate the catchment boundaries, we defined outlet points along the ice calving front. From the calculated flow network, we identified three outlet points. We then followed a flow-direction grid backwards from these outlet points, and determined all of the cells that drain through a given outlet. The edges of these grid cells represent the boundary of the ice-shelf catchments shown in Fig. 1a.

We also applied this approach to estimate the routing for the other four large Antarctic ice shelves (Fig. 4) using Bedmap2 surface topography.

Mapping water areas and depth categories. We used data collected by the Landsat- 8 sensor to estimate water area and depth over our study region. Landsat- 8 was launched in 2013 and hosts the operational land imager (OLI) spectrometer, suitable for lake area and depth estimation (http://landsat.usgs.gov/landsat8.php). The OLI has enhanced (12-bit) radiometric resolution with respect to its (8-bit) predecessors, a higher signal-to-noise ratio, and an expanded dynamic range compared with Landsat-7's enhanced thematic mapper plus (ETM+). Optical data can be used to extract both the area and the depth of supraglacial ponds using a combination of bands ${ }^{31-33}$. The increased scene-collection rate of Landsat- 8 has also lead to increased area coverage by the sensor. Landsat- 8 surface reflectance values used in this study were obtained from EarthExplorer (http://earthexplorer. usgs.gov/). Only images with less than $10 \%$ cloud cover were used (Extended Data Figs 4, 5). For each of the Landsat-8 scenes, we computed the normalized difference water index adapted for ice $\left(\mathrm{NDWI}_{\mathrm{ice}}\right)^{25}$, defined as:

$$
\mathrm{NDWI}_{\mathrm{ice}}=\left(\frac{(\mathrm{B} 1-\mathrm{B} 2)}{(\mathrm{B} 1+\mathrm{B} 2)}\right)
$$

where $\mathrm{B} 1$ and $\mathrm{B} 2$ represent the blue and red bands respectively. Owing to the spectral dependency of water reflectance, those areas with deeper water will result in pixels with higher $\mathrm{NDWI}_{\mathrm{ice}}$ values, and vice versa. Following ref. 25, we use the following thresholds to distinguish shallow, medium and deep waters: pixels that satisfy the condition $0.12<\mathrm{NDWI}_{\text {ice }}<0.14$ are classified as shallow water/slush; those satisfying the condition $0.14<\mathrm{NDWI}_{\text {ice }}<0.25$ are classified as medium-deep water; and those satisfying $\mathrm{NDWI}_{\mathrm{ice}}>0.25$ are classified as deep water (for example, ponds) (see Extended Data Fig. 5).

We tested these NDWI thresholds, which had been identified over Greenland ${ }^{25}$, in our study area, to evaluate whether we could use the same ranges of NDWI to detect water in Antarctica. We identified a lake (red star in Extended Data Fig. 4a) and a region over the ocean (dark rectangle in Extended Data Fig. 4a) in Landsat images from six days in the summer months of November 2013 through January 2014. The NDWI thresholds over the lake ranged from 0.11 to 0.5 as the season progressed from early to late summer. The ocean NDWI ranged from 0.4 to 0.55 . Although ground measurements are necessary to validate whether the shallow, medium and deep thresholds identified over Greenland are valid over Antarctica, this exercise demonstrates that the NDWI was sensitive to the amount of surface melt as summer progressed. On 26 December 2013 (2013 360), where the waterfilled lake is visible on the satellite image, we calculated an NDWI of 0.35 . The ocean in the same image had an NDWI of 0.47 (Extended Data Fig. 4b).

Mapping water depth. Water depth $(z)$ for the locations identified as covered with water (according to the NDWI analysis) was estimated using the following procedure. The expression for reflectance immediately below the water surface for optically shallow, homogeneous water, $R\left(0^{-}\right)$, is given by ${ }^{34}$ :

$$
R\left(0^{-}\right)=R_{\infty}+\left(\mathrm{Ad}-R_{\infty}\right) \exp (-g z)
$$

where Ad is the irradiance reflectance (albedo) of the bottom and $R_{\infty}$ is the irradiance reflectance of an optically deep water column. Solving this equation for $z$ gives:

$$
z=-\left(\ln \left(\operatorname{Ad}-R_{\infty}\right)-\ln \left(R\left(0^{-}\right)-R_{\infty}\right)\right) / g
$$

The value of $R_{\infty}$ is obtained from deep water (ocean) pixels within the scene, while the Ad value is obtained from pixels surrounding body waters and following the approach of ref. 35. The coefficient $g$ accounts for losses in both upward and downward directions ${ }^{34}$ and is given by ${ }^{34} g \approx K_{\mathrm{d}}+a \mathrm{Du}$, where $K_{\mathrm{d}}$ is the diffuse attenuation coefficient for downwelling light, $a$ is the beam absorption coefficient, and Du is an upwelling light distribution function or the reciprocal of the upwelling average 
$\operatorname{cosine}^{36}$. The two attenuation coefficients, $g$ and $K_{\mathrm{d}}$, are spectrally similar as long as the diffuse attenuation is not dominated by scattering. However, $K_{\mathrm{d}}$ and $g$ cannot be used interchangeably and a possible range of $1.5 K_{\mathrm{d}}<g<3 K_{d}$ can be assumed in the case of strongly absorbing waters. In ref. $34, g$ is approximated to $2 K_{d}$ for purposes of computation (see Table 1 of ref. 34). Here, we use the $K_{\mathrm{d}}$ values of optically pure water ${ }^{37}$. See Extended Data Fig. 5.

Record of calving on the Nansen Ice Shelf. There is evidence for three major calving events from the Nansen Ice Shelf since it was first studied in 1908. The sporadic pre-satellite record makes precise timing of the events impossible. The first complete mapping of the ice shelf was presented in the sketch map by the Northern Party 1912 and indicated that the ice shelf extended past Inaccessible Island. Subsequent imaging of the ice shelf in 1956 in the USGS TMA photographs revealed that the ice front had retreated. Thus the first calving occurred sometime between 1912 and 1955. Over the following years (1956-1963), the TMA imagery mapped the forward advance of the ice front, as well as the growth of the 'Grand Chasm' across the ice shelf. The next calving event occurred between the 1963 TMA image and the first satellite data in 1972. The iceberg produced in this event had a surface area of $170 \mathrm{~km}^{2}$. The most recent calving event occurred on 7 April 2016 and was observed from satellite imagery.

Water velocity from geometry and video. We used two methods to determine order-of-magnitude estimates of the water velocity and flux in the shear-margin river in January 2014: the Manning's equation and analysis of video using feature tracking.

Our approach is based on earlier work on surface streams ${ }^{38,39}$. The first approach incorporates the Manning's equation for open-channel flow and has been used previously on glaciers ${ }^{39}$. The volume flow rate, $Q$, through the surface channel is given by:

$$
Q=V A=\frac{1}{n} R_{\mathrm{h}}^{2 / 3} S^{1 / 2}
$$

where $V$ is the velocity; $A$ is the cross-sectional area of the flow; $R_{\mathrm{h}}=A / P$ and is the hydraulic radius; $P$ is the wetted perimeter; $S$ is the slope of the channel; and $n$ is the Manning coefficient $(n=0.015)$. The cross-sectional area of the flow and wetted perimeter of the channel were determined from Landsat- 8 imagery analysis from a satellite image taken on 9 January 2014 together with the IceBridge laser altimetry. The slope of the channel is determined from the Bedmap2 surface DEM, which was compared with ATM lidar measurements taken in November 2013 from the NASA P3 IceBridge missions. The flow-speed estimate obtained from this analysis is between $1.39 \mathrm{~m} \mathrm{~s}^{-1}$ and $2.17 \mathrm{~m} \mathrm{~s}^{-1}$, and the volume flow rate is between $259 \mathrm{~m}^{3} \mathrm{~s}^{-1}$ and $806 \mathrm{~m}^{3} \mathrm{~s}^{-1}$. The variability in these estimates depends on the choice of channel cross-section (for example, rectangular or triangular) that controls the hydraulic radius.

The video-based feature-tracking estimate is derived from a video shot from a research helicopter on 12 January 2014 (see Supplementary Videos). The video was stabilized for motion in post processing. Imagery was spatially calibrated using ground-control points in the video that matched up with the same features in satellite imagery (Landsat-8; 4 January 2014). At every cross-channel location, we generate a space-time plot that shows features moving at a given speed as determined by the slope of the feature in the space-time plot ${ }^{40}$. We use the Radon transform to automate the determination of the along- and cross-channel velocity components. Our velocity estimates average $0.43 \mathrm{~m} \mathrm{~s}^{-1}$ and $0.53 \mathrm{~m} \mathrm{~s}^{-1}$ for the two videos that gave the best perspective to implement this technique. Using the same channel area estimates as applied in the previous technique, we estimate a volume flow rate of between $80 \mathrm{~m}^{3} \mathrm{~s}^{-1}$ and $197 \mathrm{~m}^{3} \mathrm{~s}^{-1}$

Waterfall fluxes and exports. We have identified eight melt seasons between 2006 and 2015 for which there is sufficient satellite coverage to examine the development of the waterfall and to quantify the duration of meltwater export off the ice shelf. We use the temperature record from Mario Zucchelli Station, Terra Nova Bay, to constrain the regional temperature. An alternative would be to use the output from a regional climate model applied to Antarctica. Such model results are spatially distributed and often provide daily outputs, but freely available products such as RACMO have a spatial resolution that is too low to resolve the surface catchments of Nansen Ice Shelf effectively; one RACMO grid cell encompasses almost the entire Nansen Ice Shelf ${ }^{41}$

The melt seasons analysed are years with a minimum of three January images available with which to quantify the waterfall duration. These years range from very warm years with extensive surface melt (2013-2014) to relatively cold years during which there was little surface melt (2006-2007). An examination of these years allows us to elucidate the relationship between surface temperatures and the amount of surface melt exported from the Nansen Ice Shelf. We use the images from these eight melt seasons to determine the volume of water exported from the ice shelf using our flux estimates from 2014. The eight melt seasons with well resolved melt sequences are: 2006-2007, 2008-2009, 2009-2010, 2010-2011, 2011-2012, 2012-2013, 2013-2014 and 2014-2015 (Extended Data Table 2).
The Nansen waterfall generally develops in late December or early January. 3 January is the average start date for the waterfall, with the earliest observed date being 26 December (in 2010), and the latest start of export being 13 January (in 2013). (The temperatures at Mario Zucchelli Station on Terra Nova Bay on the date of the first observed waterfall were as follows: 26 December $2010,2.2^{\circ} \mathrm{C}$; 29 December $2008,1.38^{\circ} \mathrm{C}$; 2 January $2014,2.64^{\circ} \mathrm{C}$; 2 January $2015,0.44^{\circ} \mathrm{C}$; 7 January $2012,2.28^{\circ} \mathrm{C}$; 16 January 2013 (latest waterfall onset), $1.87^{\circ} \mathrm{C}$.) No waterfalls were imaged in two years: 2006-2007, when the average maximum December temperature at Mario Zucchelli Station was $-0.41^{\circ} \mathrm{C}$; and $2009-2010$, when the average December temperature was $0.77^{\circ} \mathrm{C}$.

The time period during which Landsat imagery resolves a shear-margin river draining in a waterfall is assumed to be the minimum export duration. There is a positive relationship between the number of days in a melt season during which the minimum temperature measured at Mario Zucchelli Station exceeded $0{ }^{\circ} \mathrm{C}$, and the duration of meltwater export (Extended Data Fig. 6). In some years no waterfall is observed (2006-2007 and 2009-2010). For the years in which the waterfall is observed, the duration of export extends from 5 to 25 days. Owing to the low temporal resolution of the Landsat imagery, these estimates represent the minimum export duration. On the basis of the spacing of the images, we estimate the uncertainty in duration of the waterfall ranges to be from 1 to 20 days. The average uncertainty of our duration estimation is 9.4 days. Despite these uncertainties, the positive relationship between the number of days in which the minimum temperature in Terra Nova Bay exceeds $0^{\circ} \mathrm{C}$ and the duration of the waterfall export indicates that the surface meltwater system removes more water in warmer years, when more melt is produced.

Next, we use the conservative meltwater export duration to determine how much melt is removed from the ice shelf by the waterfall in different years. We define the conservative export duration as the minimum number of days during which the waterfall is active. The Manning method, based on the satellite-derived DEMs from 9 January 2014, produces a minimum flux estimate of $260 \mathrm{~m}^{3} \mathrm{~s}^{-1}$. We determine how much water is exported for each year, assuming that this flux is maintained throughout the period during which the waterfall is observed. The daily volume exported is $0.02246 \mathrm{~km}^{3}$ at the minimum Manning flux. The annual export volume varies with the changing waterfall duration.

We compare these export volumes with the average annual estimated surface melt $\left(0.5 \mathrm{~m} \mathrm{yr}^{-1}\right)$ and the amount of damage that present models assume the ice sheet will sustain annually $\left(1.5 \mathrm{~m} \mathrm{yr}^{-1}\right)$ (Extended Data Fig. 7). We calculate the melt volumes in these two conditions for the catchment area drained by the Nansen shear-margin river $\left(331 \mathrm{~km}^{2}\right)$. The average annual surface melt is from stake measurements of surface mass loss by an Italian field program in the 1990s. A water volume of $0.16 \mathrm{~km}^{3}$ is produced in the shear-margin catchment in an average melt season. The damage threshold is based on the amount of surface melt that begins to damage an ice shelf $\left(1.5 \mathrm{~m} \mathrm{yr}^{-1}\right)$ used in the Antarctic ice-sheet model of ref. 4. At the low-end Manning flux, the shear-margin river removes the average annual melt in 7 days and the damage threshold melt in 21 days.

Presence of surface water export in Greenland. We present Landsat satellite imagery and preliminary mapping of water extent from the ice shelf in front of Petermann Glacier in northwest Greenland. Although active surface rivers are present in many of the Petermann ice shelf images, no mapping of their extent, depth or persistence has been reported. Greenpeace captured iconic photos of the Petermann 'Blue' River during a 2009 expedition when the team kayaked in the river. We present Landsat images of the Petermann River from 15 July 2014 in Extended Data Fig. 8 (Landsat scene identifier LC80450012014196LGN00), and have calculated the water extent, finding that this $50-190 \mathrm{~m}$ wide river is exporting meltwater off the ice shelf into the fjord.

Data availability. The data used in this analysis are available at public repositories including the National Snow and Ice Data Center (https://nsidc.org; IceBridge data and Bedmap2 DEM), the Scott Polar Research Institute, University of Cambridge (http://www.spri.cam.ac.uk; photos presented in Fig. 2), and the USGS/Landsat/ TMA photo collections (https://earthexplorer.usgs.gov/).

28. Wright, C. S. \& Priestley, R. E. in Glaciology 581 (Harrison and Sons, 1922).

29. Chu, W. Creyts, T. T. \& Bell, R. E. Rerouting of subglacial water flow between neighboring glaciers in West Greenland. J. Geophys. Res. 121, 925-938 (2016).

30. Tarboton, D. G. A new method for the determination of flow directions and upslope areas in grid digital elevation models. Wat. Resour. Res. 33, 309-319 (1997).

31. Pope, A. et al. Estimating supraglacial lake depth in West Greenland using Landsat 8 and comparison with other multispectral methods. Cryosphere 10, 15-27 (2016).

32. Legleiter, C. J., Tedesco, M., Smith, L C., Behar, A. E. \& Overstreet, B. T. Mapping the bathymetry of supraglacial lakes and streams on the Greenland ice sheet using field measurements and high-resolution satellite images. Cryosphere $\mathbf{8 ,}$ 215-228 (2014).

33. Tedesco, M. \& Steiner, N. In-situ multispectral and bathymetric measurements over a supraglacial lake in western Greenland using a remotely controlled watercraft. Cryosphere 5, 445-452 (2011) 


\section{LETTER RESEARCH}

34. Philpot, W. D. Bathymetric mapping with passive multispectral imagery. Appl. Opt. 28, 1569-1578 (1989)

35. Sneed, W. A. \& Hamilton, G. S. Evolution of melt pond volume on the surface of the Greenland Ice Sheet. Geophys. Res. Lett. 34, L03501 (2007).

36. Mobley, C. D., Stramski, D., Bissett, W. P. \& Boss, E. Optical modeling of ocean waters: is the case 1-case 2 classification still useful? Oceanography 17, 60-67 (2004).

37. Jones, P. D. \& Moberg, A. Hemispheric and large-scale surface air temperature variations: an extensive revision and an update to 2001. J. Clim. 16, 206-223 (2003).
38. Jarosch, A. H. \& Gudmundsson, M. T. A numerical model for meltwater channel evolution in glaciers. Cryosphere 6, 493-503 (2012).

39. Fountain, A. G. \& Walder, J. S. Water flow through temperate glaciers. Rev. Geophys. 36, 299-328 (1998).

40. Jessup, A. T., Zappa, C. J. \& Yeh, H. Defining and quantifying microscale wave breaking with infrared imagery. J. Geophys. Res. 102, 23145-23153 (1997).

41. Van Wessem, J. M. et al. Improved representation of East Antarctic surface mass balance in a regional atmospheric climate model. J. Glaciol. 60, 761-770 (2014) 


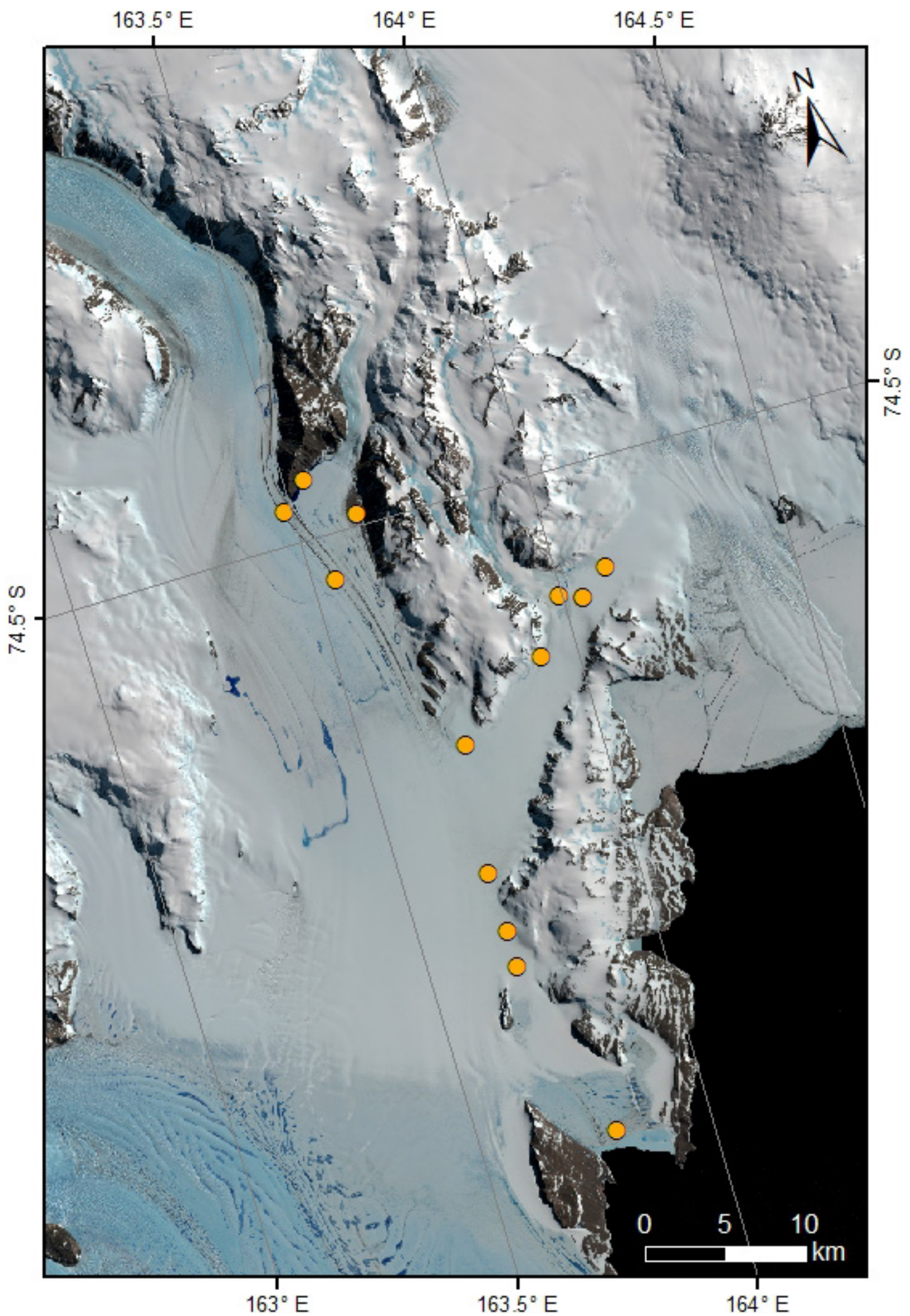

Extended Data Figure 1 | Locations of Northern Party campsites. Detailed information is included in Extended Data Table 1. 
a)

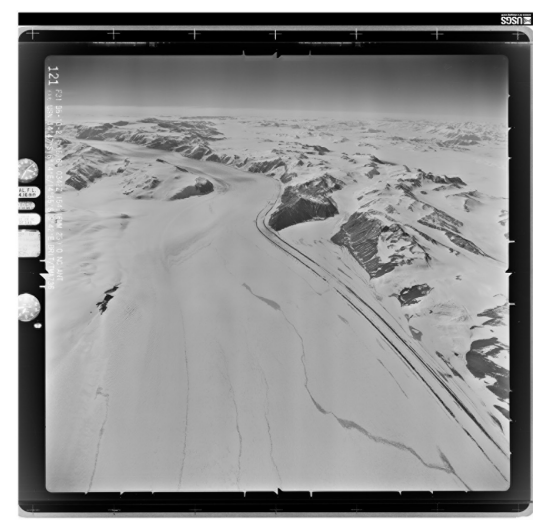

b)

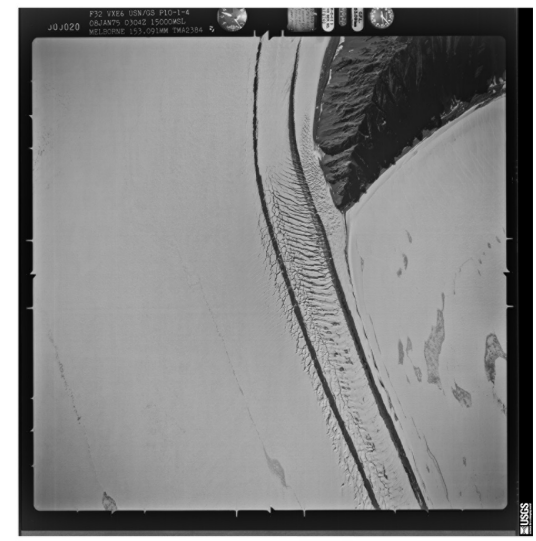

c)

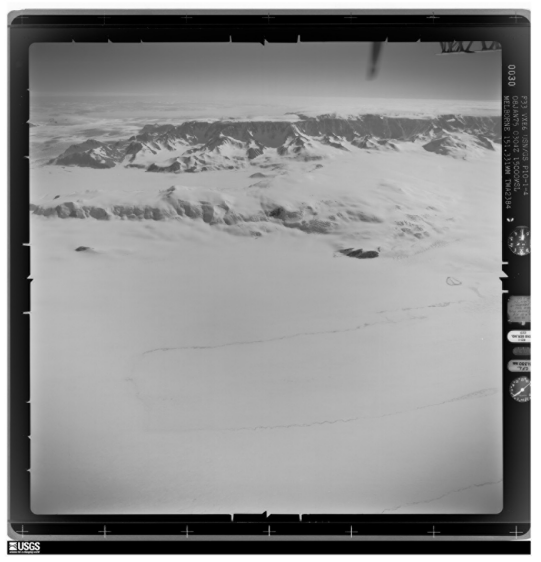

Extended Data Figure 2 | Firn- and mélange-terminating surface drainage on the Nansen Ice Shelf. a, Aerial photograph of a firnterminating system, showing a water-filled ravine and surface streams (TMA identifier CA073631L021, https://earthexplorer.usgs.gov/; 15 January 1961). b, Aerial photograph of a firn-terminating system, showing ponds, a water-filled ravine and surface streams (TMA identifier CA238432V0020; 8 January 1975,).c, Aerial photograph of a firnterminating system, showing surface streams that terminate in firn

d)

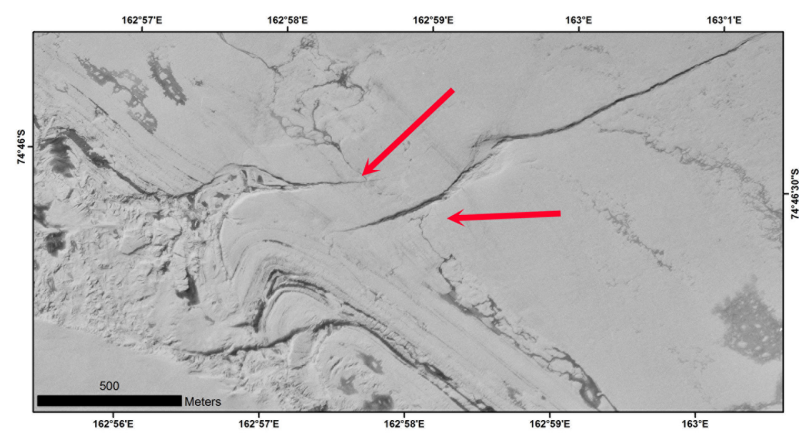

e)

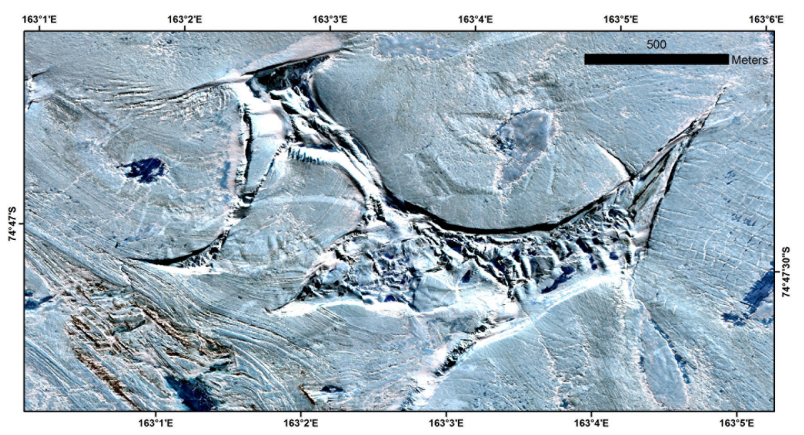

f)

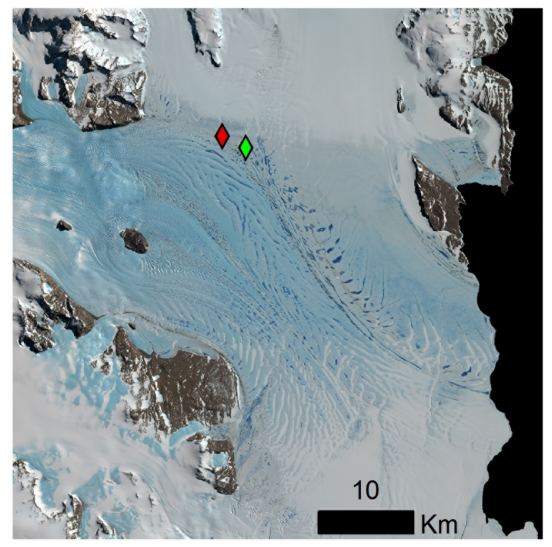

(TMA identifier CA238433R0030; 9 January 1975. d, Surface meltwater drainage into rifted mélange, with red arrows locating drainage points. (Aerial photograph from 1975; TMA identifier CA238332V0060.) e, Surface meltwater drainage into rifted mélange. (Worldview satellite photograph from 10 February 2014.) f, Location of the surface drainage images shown atop a Landsat image. Fig. $2 \mathrm{~d}$ is shown as a red diamond and Fig. 2e as a green diamond. 

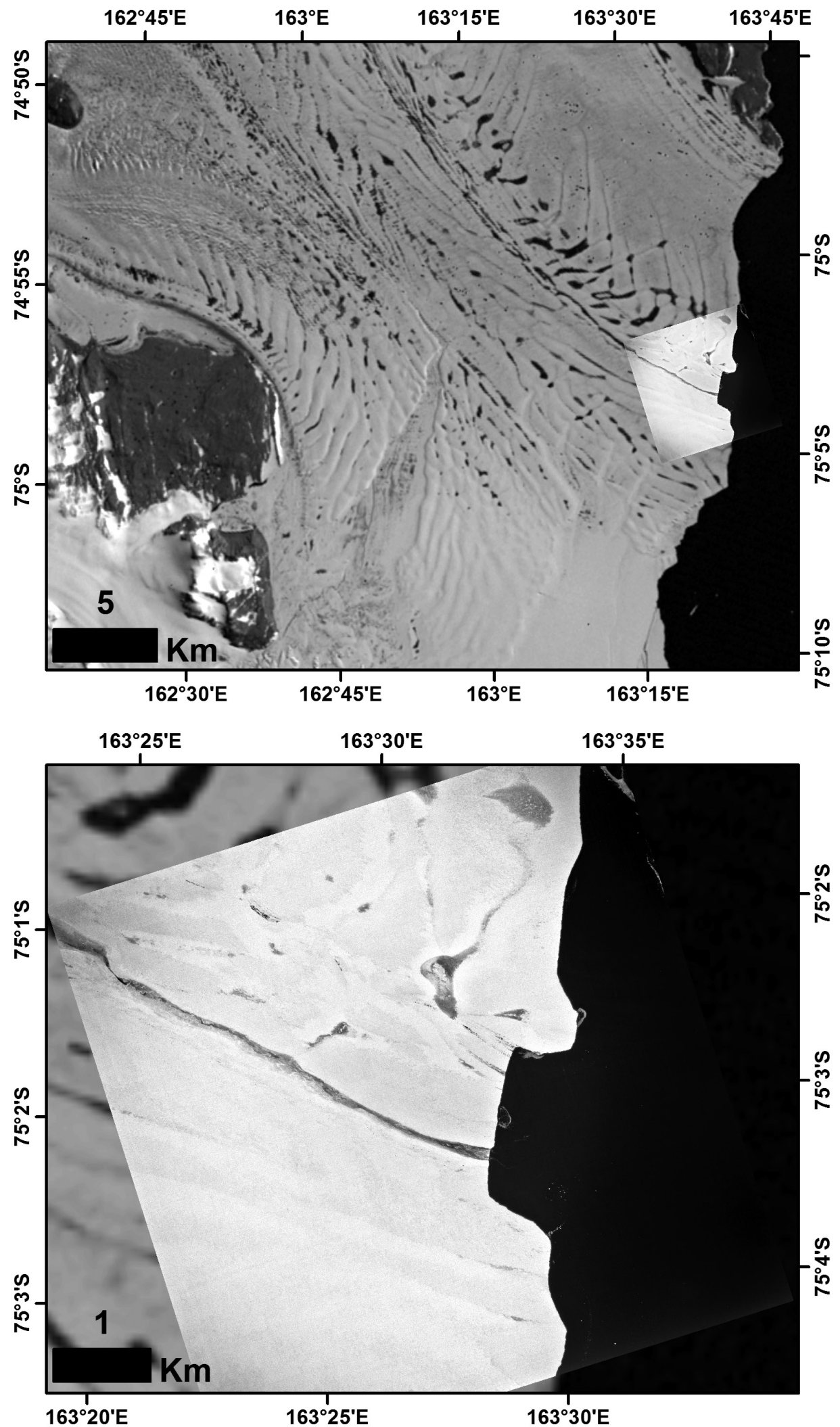

Extended Data Figure 3 Shear-margin river and waterfall in

1974-1975. Top, a Landsat image from 16 January 1974 (Landsat scene identifier LM10641141974016AAA02, from https://earthexplorer.usgs. gov/), and shows a well defined surface drainage network, including a calving-front waterfall. Bottom, TMA image of the 1975 waterfall, shot on 8 January 1975 (vertical-camera image reference is TMA photograph CA238432V0063).The TMA photograph is overlain on the Landsat image in the upper panel. 
(a)

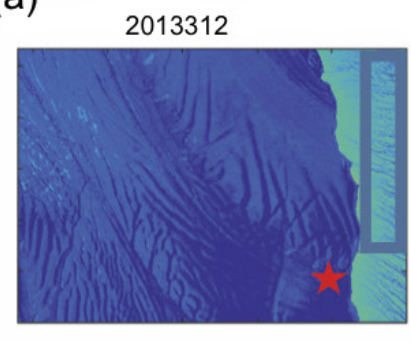

2014002

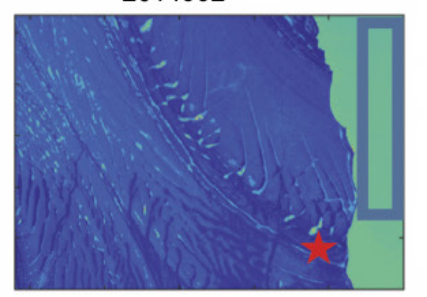

2013344

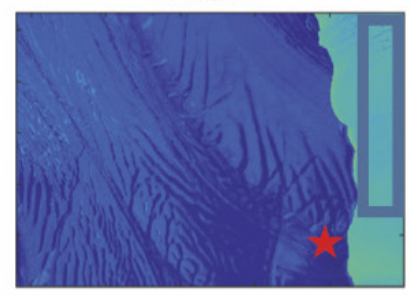

2014005

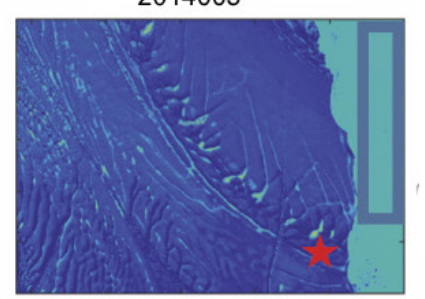

2013360

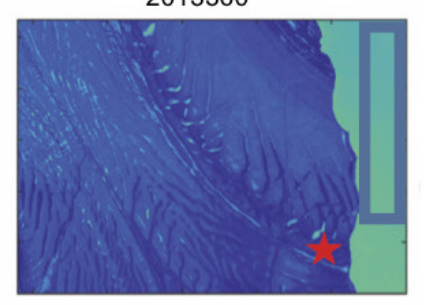

NDWI

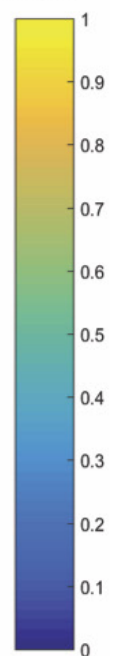

(b)

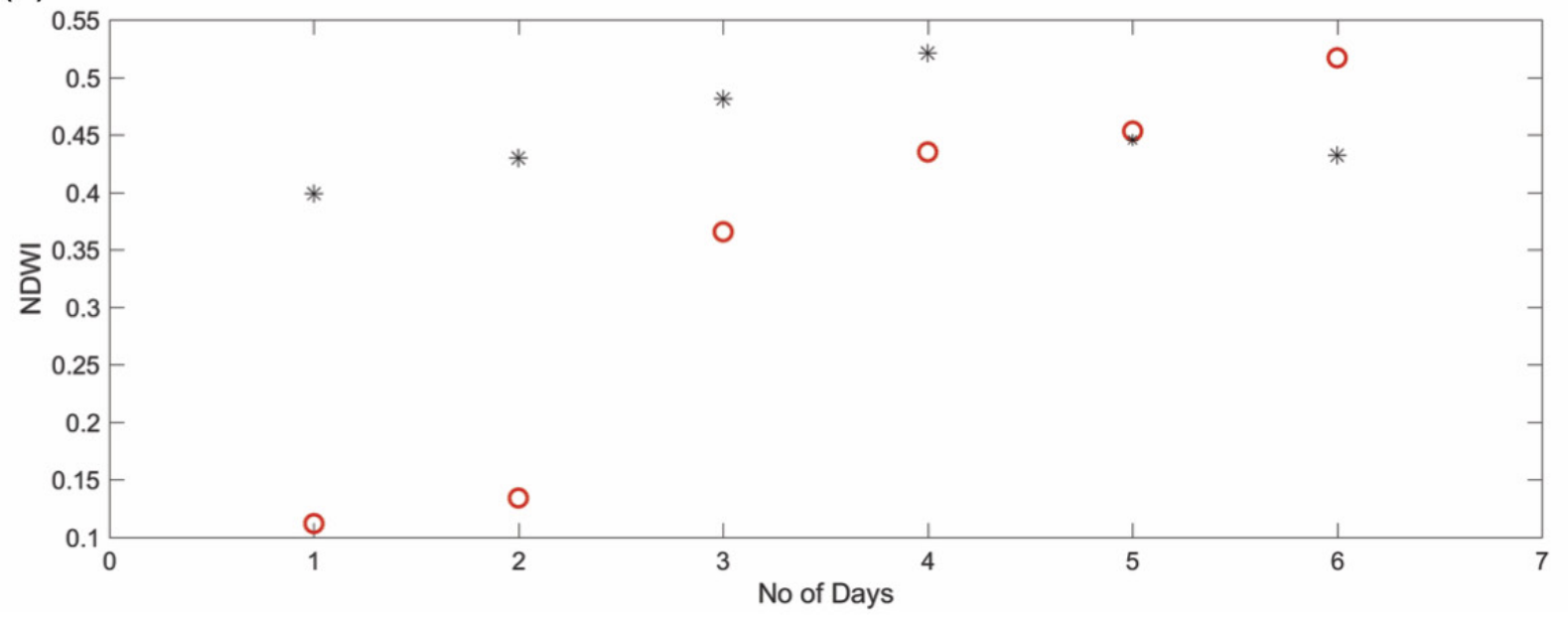

(c)

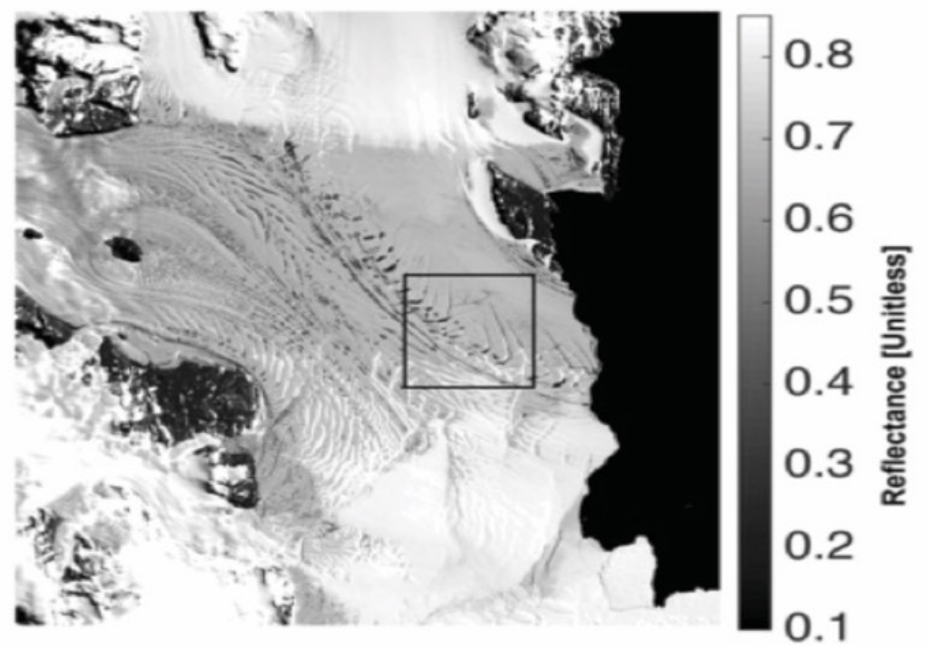

Extended Data Figure $4 \mid$ NDWI sensitivity. a, NDWI values obtained for six days, over the ocean (rectangular boxes) and the ice shelf (specifically, a lake, identified by a red star), showing how NDWI changes as summer progresses. The variability in the ocean values reflects the varying extent of sea ice on Terra Nova Bay, and the spectral properties of the atmospheric column above it. Numbers above each image are the year followed by the Julian day. b, Means of NDWI for the 2013-2014 melt season over the ocean (black star) and over a 'deep' lake/pond (red circle; located in c). This panel shows the validity of our $>0.25$ threshold for locating deeper water over the Nansen Ice Shelf. c, Map of Landsat-8 red-channel reflectance (636-673 $\mathrm{nm}$, unitless) for the image acquired on 4 January 2014. The black box shows the region for which our quantitative analysis of NDWI-based water extent and depth was performed. 


\section{RESEARCH LETTER}
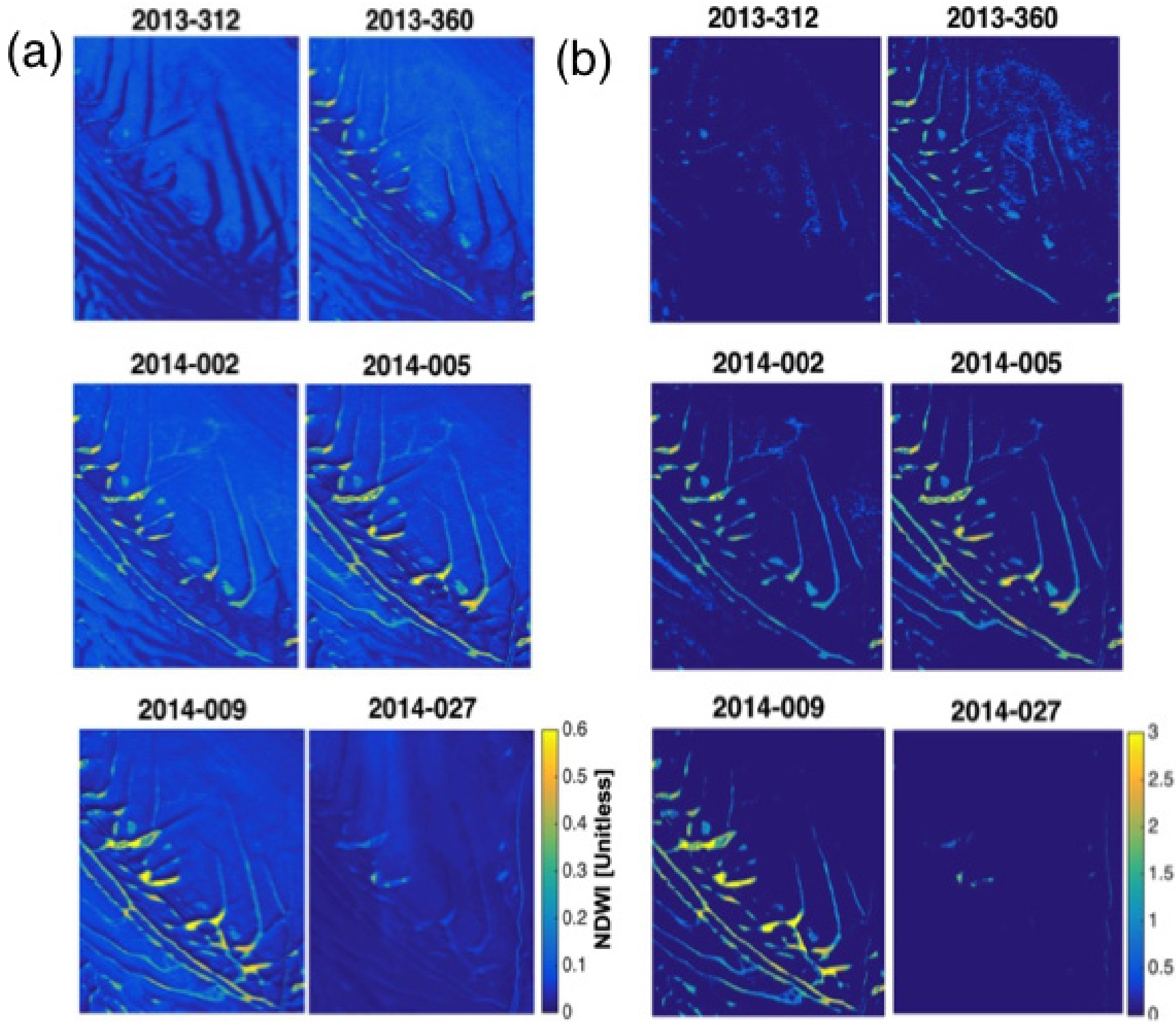

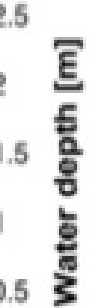

Extended Data Figure 5 | Water extent and depth. a, Maps of NDWI-based water-extent values over the area contained within the black box of Extended Data Fig. 4. The date for each image is given at the top of each panel. b, Maps of derived water-depth values over the same area. 


\section{a) Minimum Temperature Above $0^{\circ} \mathrm{C}$ (Days)}

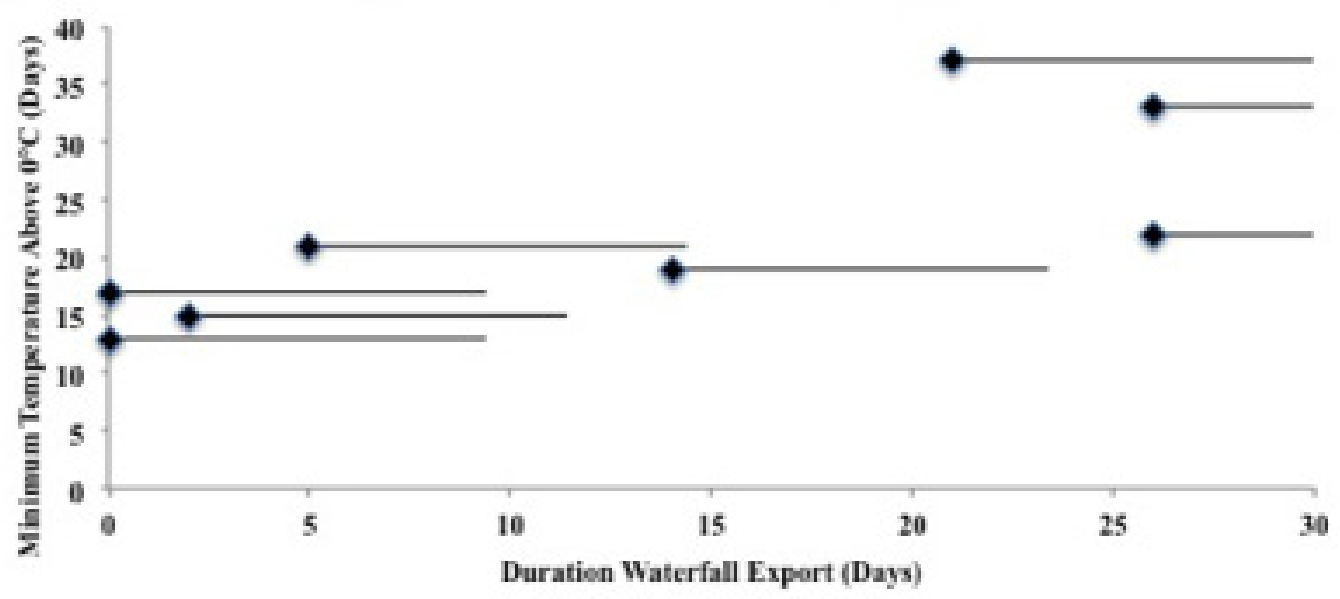

\section{b) Water Volume Exported for Observed Waterfall}

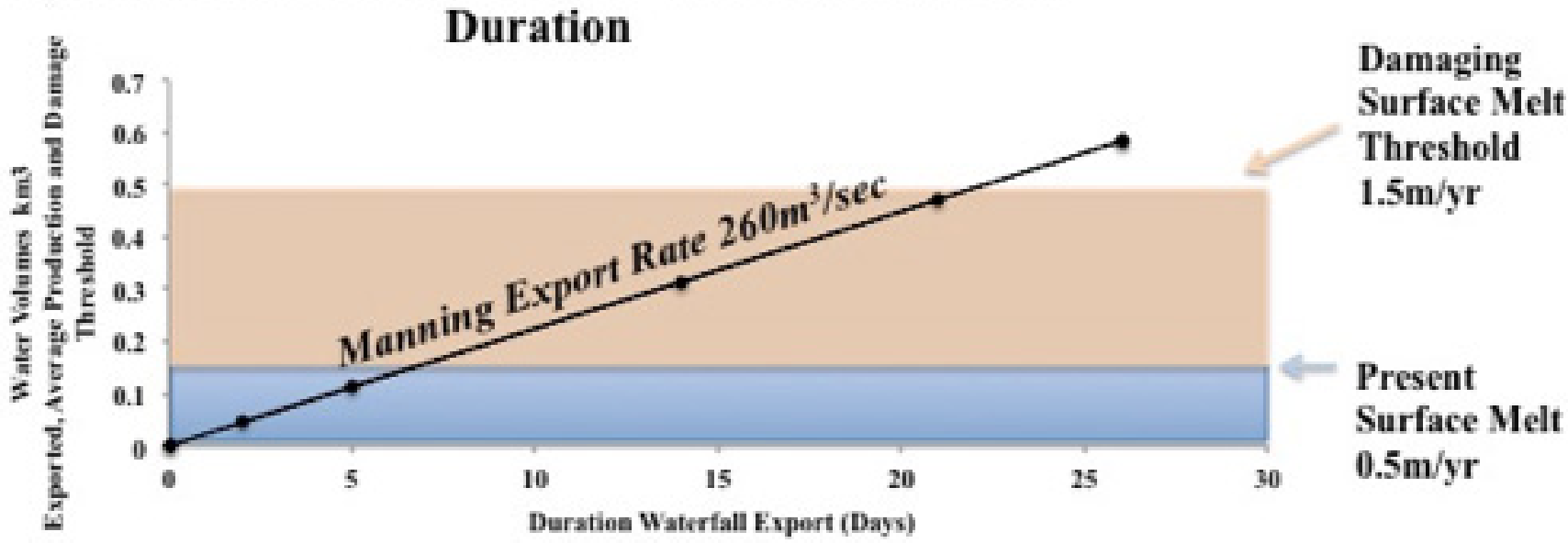

Extended Data Figure 6 | Waterfall export and duration. a, Duration of waterfall export in the eight years for which there is adequate satellite imagery, plotted against the number of days in which the minimum temperature was above $0^{\circ} \mathrm{C}$, at Mario Zucchelli Station on Terra Nova Bay. Error bars for waterfall duration are 9.4 days. The duration of export increases with increasing temperature. $\mathbf{b}$, Estimates of the volume of surface melt water exported. The export line for the observed waterfall export durations is calculated using the Manning flux estimate $\left(260 \mathrm{~m}^{3} \mathrm{~s}^{-1}\right)$. This line is compared with the melt volume produced at present in the calving-front catchment at a surface melt rate of $0.5 \mathrm{~m} \mathrm{yr}^{-1}$, and the melt volume that would be produced if the surface melt rate were $1.5 \mathrm{~m} \mathrm{yr}^{-1}$. The present-day melt volume of $0.16 \mathrm{~km}^{3}$ is shown in blue; the damaging melt volume of $0.49 \mathrm{~km}^{3}$ is shown in tan. The melt volume of $1.5 \mathrm{~m} \mathrm{yr}^{-1}$ is considered damaging in the present ice-sheet models. 


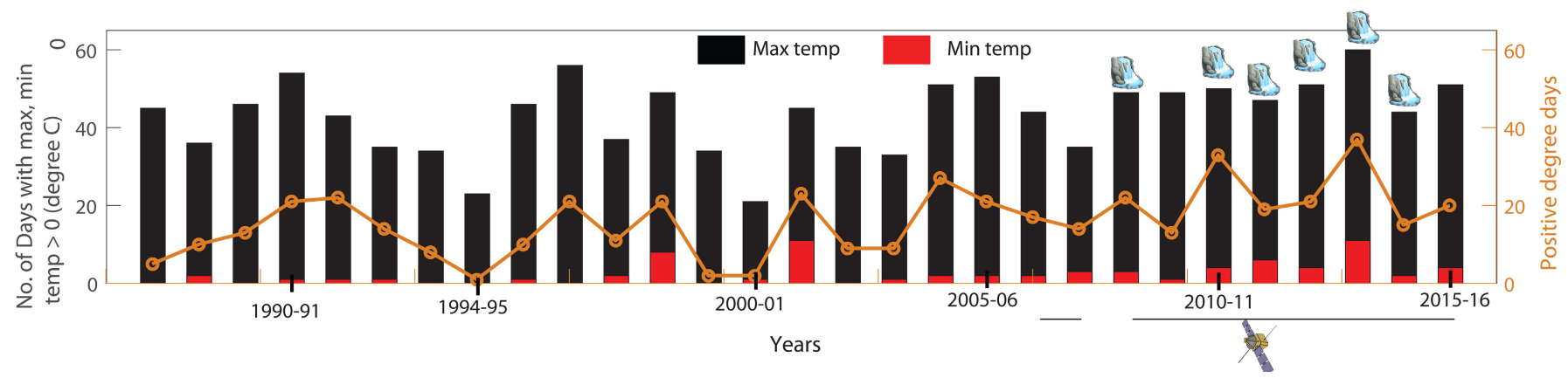

Extended Data Figure 7 | Temperature record for Mario Zucchelli Station on Terra Nova Bay for 1986-2016. The brown line indicates the number of days for which the temperature was positive during this period. Black bars show the number of days when the maximum temperature exceeded $0{ }^{\circ} \mathrm{C}$, and the red bars indicate the number of days when the minimum temperature exceeded $0^{\circ} \mathrm{C}$. There is no statistically significant increase in the temperature at Terra Nova Bay over this time period. The line at the bottom indicates the years for which we have sufficient satellite imagery to resolve whether the surface hydrology was exporting water off the ice shelf. The years during which we identified export at a waterfall are indicated with a waterfall symbol. These temperature data are available at http://www.climantartide.it. 


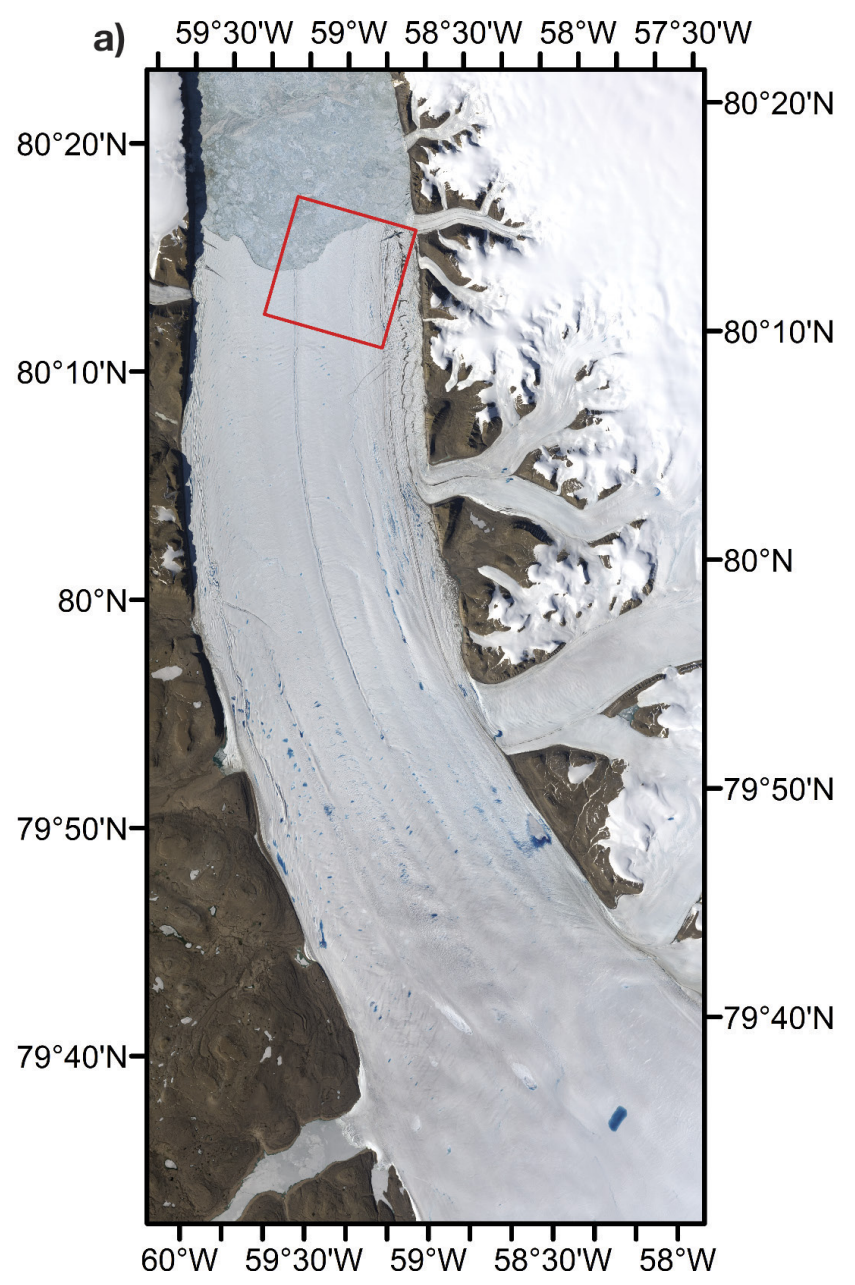

Extended Data Figure 8 Petermann Glacier and adjacent ice shelf with river. a, Landsat image of the Petermann Ice Shelf River, taken on 15 July 2014. The red outline shows that area that is expanded in $\mathbf{b}$. b. Expanded b)

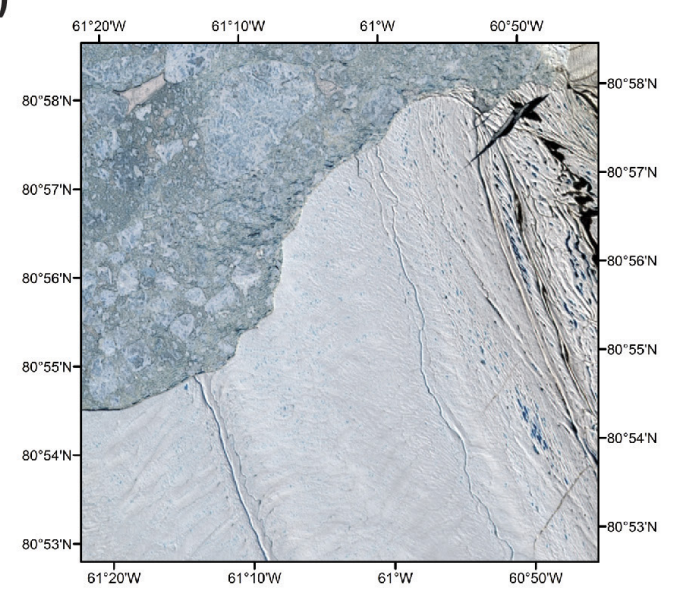

c)

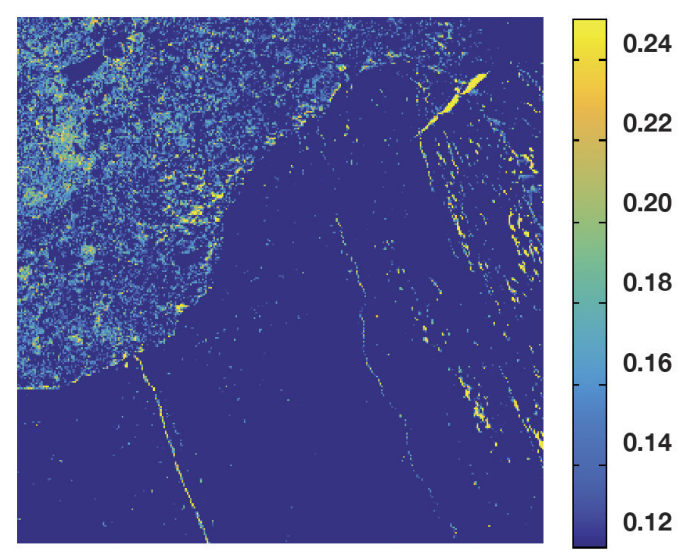

image of the Peterman Ice Shelf River at the calving front. c, NDWI analysis of water distribution in $\mathbf{b}$, obtained using the methodology used for the Nansen Ice Shelf. 


\section{RESEARCH LETTER}

Extended Data Table 1 | Location of the major camps of the Northern Party 1912

\begin{tabular}{|c|c|c|c|}
\hline Date & Latitude & Longitude & Notes \\
\hline Jan 9 & $-74.764864^{\circ}$ & $163.688858^{\circ}$ & Snow in Levick's sleeping bag \\
\hline Jan 10 & $-74.744328^{\circ}$ & $163.688548^{\circ}$ & \\
\hline Jan 11 & $-74.709775^{\circ}$ & $163.686466^{\circ}$ & At entrance Campbell Glacier \\
\hline Jan 12 & $-74.575099^{\circ}$ & $164.043346^{\circ}$ & Looking up Boomerang Glacier \\
\hline Jan 13 & $-74.575099^{\circ}$ & $164.043346^{\circ}$ & Looking up Boomerang Glacier \\
\hline Jan 14 & $-74.562088^{\circ}$ & $164.107371^{\circ}$ & Icefalls not Boomerang Glacier \\
\hline Jan $15-20$ & $-74.570626^{\circ}$ & $163.992558^{\circ}$ & $\begin{array}{l}\text { Camp on moraine Boomerang } \\
\text { Glacier confined to tent in } \\
\text { snowstorm } 4 \text { days }\end{array}$ \\
\hline Jan 21 & $-74.601070^{\circ}$ & $163.922355^{\circ}$ & Snowblind camp \\
\hline Jan 23-26 & $-74.636430^{\circ}$ & $163.715124^{\circ}$ & Camp Sustrugi \\
\hline Jan 27 & $-74.526364^{\circ}$ & $163.548070^{\circ}$ & Fossil moraine discovery \\
\hline $\operatorname{Jan} 28$ & $-74.493771^{\circ}$ & $163.631332^{\circ}$ & Granite moraine no fossils \\
\hline Jan $29-30$ & $-74.467796^{\circ}$ & $163.545033^{\circ}$ & $\begin{array}{l}\text { Northern lateral moraine Corner } \\
\text { Glacier abundant running water }\end{array}$ \\
\hline $\begin{array}{l}\text { Jan 31- } \\
\text { Feb2 }\end{array}$ & $-74.481651^{\circ}$ & $163.484727^{\circ}$ & Fossil moraine again \\
\hline
\end{tabular}


Extended Data Table 2 | Satellite coverage available for specific melt seasons (December and January)

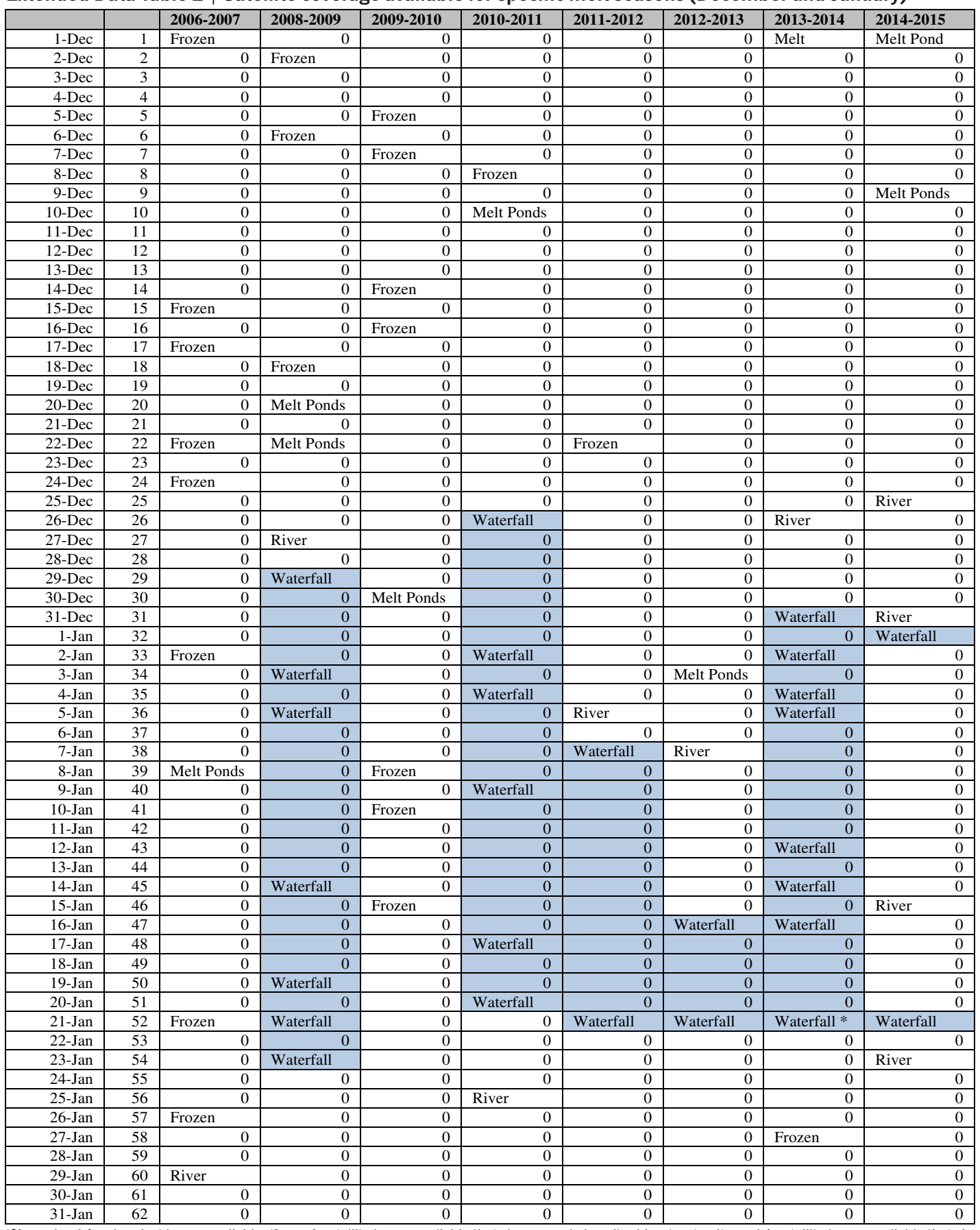

' 0 ', no cloud-free Landsat image available; 'frozen', satellite image available that shows no obvious liquid water; 'melt ponds', satellite image available that shows water collecting in surface depressions; 'river', satellite image available that shows water along the shear margin; 'waterfall', satellite image available showing a shear-margin river terminating at a waterfall. 